\title{
THE ENFORCEMENT OF PERSONAL LIABILITY ON MORTGAGE DEBTS IN NEW YORK**
}

\author{
MILTON R. FRIEDMAN $†$
}

THE traditional remedy of a mortgagee is foreclosure. Under the common law, a mortgage was a conveyance of title defeasible on payment of the debt. On default the mortgagee, as legal owner, took possession or brought ejectment at law against the mortgagor. But from an early period the mortgagor could go into equity and stay the legal action so as to permit subsequent redemption. Consequently, the mortgagee came to initiate his proceeding in equity by praying for an order directing the mortgagor to redeem within a specified time or be foreclosed of all interest in the premises. ${ }^{1}$ Thus to relieve the mortgagor from forfeiture, ${ }^{2}$ chancery, along with the evolution of this procedure of strict foreclosure, ${ }^{3}$ developed the doctrine of equity of redemption and carefully surrounded it with safeguards. ${ }^{4}$

* The validity and effect of assumption of mortgage debts in New York has recently been discussed by the author in the Journal in The Creation and Effect of Pcrsonal Lidbility on Mortgage Debts in New York (1940) 50 Y ALE L. J. 224. This article will discuss the remedies of the mortgagee before and after the emergency legislation of 1933.

t Member of the New York and Connecticut bars.

1. There is said to be an unreported case permitting redemption after sixteen years -a practice hardly designed for free alienation of property. Brabner-Smith, Economic Aspects of the Deficiency Judgment (1934) 20 VA. L. Rev. 719, 721.

2. Sears, Roebuck \& Co. v. Camp, 124 N. J. Eq. 403, 407-08, 1 A. (2d) $425,427-$ 28 (1938).

3. Barson v. Mulligan, 191 N. Y. $306,313-15,84$ N. E. $75,78,16$ L. R. A. (N. s.) 151 (1908) ; Moulton v. Cornish, 138 N. Y. 133, 140-41, 33 N. E. 842, 843-44, 20 L. R. A. 370 (1893) ; Holmes v. Gravenhorst, 238 App. Div. 313, 314-15, 263 N. Y. Supp. 738, 740-41 (2d Dep't 1933), rev'd, 263 N. Y. 148, 188 N. E. 285, 91 A. L. R. 1230, 1236 (1933); Young v. Vail, 29 N. M. 324, 369-71, 222 Pac. 912, 924, 34 A. L. R. 980, 1015 (1924).

4. Since 1830 the mortgagee's remedy of ejectment has been barred in New Yorl by statute (now Civil Practice Act $\$ 991$ ) which cannot be avoided by contract. See Prudential Ins. Co. v. Liberdar Holding Co., 74 F. (2d) 50, 53 (C. C. A. 2d, 1934). A mortgagee may no longer have possession prior to foreclosure withott the owner's con* sent. Herrmann v. Cabinet Land Co., 217 N. Y. 526, 112 N. E. 476 (1916). Waiver of the equity of redemption is forbidden, and executory contracts to convey to the mortgagee in lieu of foreclosure are unenforceable as against public policy. See Verity v. Metropolis Land Co., 248 App. Div. 748, 288 N. Y. Supp. 625 (2d Dep't 1936), aff'd, 274 N. Y. 624,10 N. E. (2d) 582 (1937); but cf. 2 JoNes, Mortgages (8th ed. 1928) $\S 878$, n. 47 , and $\S 881$, n. 90 . Dealings between mortgagor and mortgagee are subject to scrutiny by equity. See Odell v. Montross, 68 N. Y. 499, 504 (1877); 2 JoNes, op. cil. supra, at $\$ \S 878-81 ; 1$ Wiltsie, Mortgage Foreclosures (5th ed. 1939) $\$ \$ 244-45$. 
Early foreclosure procedures were in rem and no money judgments were sought or obtained." With this common law bachground Chancellor Kent, in the early New York case of Dumkley r. I an Buros, concluded that equity had no jurisdiction to enter a deficiency judgment in furcclosure. This was an exception to the general practice of equity, on assuming jurisdiction, to make a complete determination of all issues, legal and equitable. But principally because of Kent's prestige, Imerican courts have assumed since the Dunkley case that deficiency judgment: were creatures of statute alone. ${ }^{7}$ Later, strict foreclosure was sulplantul in New York by foreclosure by sale, a method deemed fairer un the ground that a public sale was the truest test of value: If the prucuculi of sale were less than the mortgage debt, the nurtgagne recovered a judgment for the deficiency, while any surplus was payalle to the mortgagor. ${ }^{8}$

\section{Rejtedies of the Mortglaee Before the Earergency Legristation}

Deficiency Judgments. Prior to the emergency legislation of 1933 . a mortgagee could by statute recover a deficiency judgment in foreclosure against his mortgagor and any person liable on the deht ${ }^{\circ}$ if the court had jurisdiction in personam ${ }^{10}$ and the judgment directing the sale adjudicated the liability of the party to be charged.11 Iudgment

5. See Mionaghan v. MIay, 242 App. Div. 64, 66, 273 N. Y. Supp. 475, 478 (2d Dep't 1934) ; Young v. Vail, 29 N. A1. 324, 369-71, 222 Pac. 012, 924, 34 A. L. R. 990, 1015 (1924).

6. 3 Johns. Ch. 330 (N. Y. 181S).

7. See Rutherford Realty Co. v. Cook, 198 N. Y. 29, 33, 90 N. E. 1112, 1113 (1910); Reichert v. Stilwell, 172 N. Y. \$3, S9, 64 N. E. 790, 792 (1902); Jamaica Sav. Banl: v. M. S. Investing Co., 274 N. Y. 215, 218, 8 N. E. (2d) 403, 112 A. L. R. 1485,1492 (1937) ; Monaghan v. May, 242 App. Div. 64, 66, 273 N. Y. Supp. 475, 478 (24 Depit 1934) ; and see the elaborate discussion in Young v. Vail, 29 N. M. 324, 222 Pac. 912, 34 A. L. R. 980, 1015 (1924).

8. Lansing v. Goelet, 9 Cow. $346,356,357$ (N. Y. 1827); Sears, Kugbusls \& Co. v. Camp, 124 N. J. Eq. 403, 407-0S, 1 A. (2d) 425, 428 (1938) ; $c$. Franls v. Davis, $135 \mathrm{~N}$. Y. $275,279,31$ N. E. 1100,1101 (1S92); National City Bank v. Gelfert, 284 N. Y. 13, 20, 29 N. E. (2d) 449, 452-53 (1940), 130 A. L. R. 1472, 1482 (1941), recd, 313 U. S. 221 (1941) ; 3 Jones, MLORTGaGes (Sth ed. 1928) § 2010.

Foreclosure by sale is said to be the common American remedy. Brabner-Smith, loc. cit. supra note 1 . The mortgagee's remedies in the various states are eatalogudi in 3 Jones, Mortgages (\$th ed. 1928) $\$ 1690$ ct seq. The remedies in England are di - cussed in Turner, The English Mortgage of Land as Securily (1934) 20 VA. L. Rew. 729.

9. N. Y. C. P. A. $\$ \$ 1079(7), 1083$.

10. Heilbrunn v. Kellog, 253 App. Div. 753, 1 N. Y. S. (24) 193 (2.1 Dep't 1937), aff'd, 279 N. Y. 773, 18 N. E. (2d) $\$ 61$ (1939); Pacel v. Furrar, 258 Arp. Uiv. 772, 14 N. Y. S. (2d) 814 (4th Dep't 1939).

11. Bankers Trust Co. v. 1 East S8th St. Co., 283 N. Y. 369,23 N. E. (24) 875 (1940); Wager v. Link, 134 N. Y. 122, 128, 31 N. E. 213, 215 (18)2); sse Sirague v. Jones, 9 Paige 395 (N. Y. 1842) (amendment of judgment). 
of foreclosure and sale was final for some purposes and interlocutory for others. It was a final order for purposes of appeal, ${ }^{12}$ but interlocutory as to the amount of the obligor's liability, which was not fixed until the entry of a money judgment. ${ }^{13}$ Not until then did execution issue. $^{14}$ If the referee's report of sale showed a deficit, the clerk of the court docketed a deficiency judgment without application to the court or notice to the obligor. ${ }^{15}$ Execution issued immediately; confirmation was neither necessary nor $\mathfrak{u s t u a l}^{16}$ and no further order was required. ${ }^{17}$ The act of the clerk was purely ministerial, ${ }^{18}$ in purstance of

12. Emigrant Indust. Sav. Bank v. Van Bokkelen, 269 N. Y. 110, 199 N. E. 23 (1935). 'The judgment of foreclosure and sale is a final determination of the rights of the parties in the premises on all matters within the scope of the pleadings. Matter of Estate of Stilwell, 139 N. Y. 338, 34 N. E. 777 (1893). The adjudication of liability is immune from collateral attack. Butterly v. Maribert Realty Corp., 234 App. Div. 424, 255 N. Y. Supp. 321 (1st Dep't 1932), aff'd, 260 N. Y. 554, 184 N. E. 89 (1932) ; 'Tillkelman v. 415 East 12th St. Corp., 251 App. Div. 377, 296 N. X. Supp. 870 (1st Dep't 1937). Fraud in obtaining the judgment may be raised subsecuently. Slote v. Cascade Holding Corp., 276 N. Y. 239, 11 N. E. (2d) 894 (1937); Byrnes v. Owen, 243 N. Y. 211,153 N. E. 51 (1926) ; Garlasco v. Smith, 250 App. Div. 534, 294 N. Y. Supp. 772 (1st Dep't 1937), aff'd, 276 N. Y. 666, 13 N. E. (2d) 53 (1938). The riglit to an accounting may also be raised subsequently. Kohl v. First Trust Co., 255 App. Div. 123,6 N. Y. S. (2d) 84 (4th Dep't 1938); see Bennett v. Austin, 81 N. Y. 308 (1880) (junior mortgagee in possession, using rents to acquire title in senior forcelosure, holds title in trust for mortgagor). A third person, not a party to the forcclosure, may not take advantage of the adjudication. St. John v. Fowler, 229 N. Y. 270, 128 N. E. 199 (1920). The judgment is interlocutory in that the right of redemption survives until the sale and until then inferior lienors may sell on execution. Nutt v. Cuming, 155 N. Y. $309,313,49$ N. E. 880,881 (1898) ; Barnard v. Onderdonk, 98 N. Y. 158,160 (1885). The auction sale terminates the right of redemption and the owner may not prevent the purchaser's completion of the sale by tender during the interin. Brown $v$. Frost, 10 Paige 243 (N. Y. 1843).

13. McCarthy v. Graham, 8 Paige 480 (N. Y. 1840); Emigrant Indust. Sav. Bank v. Van Bokkelen, 269 N. Y. $110,115,199$ N. E. 23, 25 (1935); see 3 Jonts, MokTuAar's (8th ed. 1928) $\S \S 2206,2220$.

14. French v. French, 107 App. Div. 107, 94 N. Y. Supp. 1026 (4th Dep't 1905), appeal dismissed, 185 N. Y. 532, 77 N. E. 1187 (1906); see 3 Jones, MortGanges (8th el. 1928) $\$ 2012$.

15. Bondy v. Aronson \& List Realties, Inc., 227 App. Div. 136, 237 N. Y. Supp. 444 (4th Dep't 1929); Hawley v. Whalen, 64 Hun 550, 19 N. Y. Supp. 521 (5th Dep't 1892).

16. Bondy v. Aronson \& List Realties, Inc., 227 App. Div. 136, 237 N. Y. Supp. 444 (4th Dep't 1929) ; Moore v. Shaw, 15 Hun 428 (N. Y. 1st Dep't 1878), appcal dis* missed, 77 N. Y. 512 (1879); Metropolitan Sav. Bank v. Feigenblatt, N. Y. L. J., Oct. 26, 1936, p. 1369, col. 7 (Sup. Ct.); see Syracuse Trust Co. v. Corey, 167 Misc. 506, 509 et seq., 4 N. Y. S. (2d) 349, 352-53 et seq. (Sup. Ct. 1938).

17. Taylor v. Derrick, 64 Hun 636, 19 N. Y. Supp. 785 (Sup. Ct. 1892).

18. Morris v. Morange, 38 N. Y. 172 (1868); Moore v. Shaw, 15 Hun 428 (N. Y. 1st Dep't 1878), appeal dismissed, 77 N. Y. 512 (1879). 
the judgment of foreclosure and sale. and apparently not a final urder for purposes of appeal. ${ }^{19}$

Since determination of the deficiency judgment was automatic, protection of the mortgagor depended on adequacy of price obtained at the foreclosure sale. But the foreclosure sale, although subject to vacation on various grounds of unfairness, ${ }^{20}$ could not be set aside for inadequacy of price alone ${ }^{21}$ unless it was so great as to "shock the conscience" of the court. ${ }^{22}$ Nor did the mortgagee's resale of the premises at a profit reduce the deficiency judgment. ${ }^{23}$ While the failure of judicial sales to attract bidders had previously been recognized, ${ }^{2-4}$ it was the depressiun

19. Himmelman v. 540 West 146th Street, Inc., 244 N. X. 540,155 N. E. 888 (1926).

20. King v. Platt, 37 N. Y. 155 (1867); Wright v. Caprarella, 205 App. Div. 55\%, 199 N. Y. Supp. \&64 (2d Dep't 1923); Lincoln Trust Co. v. Fullaytar, 193 Agp. Liv. 530, 190 N. Y. Supp. 630 (1st Dep't 1921), appcal dismissid, 232 N. Y. 600, 134 N. E. 588 (1922) ; Purdy v. Willins, 95 Misc. 706, 160 N. Y. Supp. 17 (Sup. Ct. 1916) ; Collier v. Whipple, 13 Wend. 224 (N. Y. 1834); Jackson v. Crafts, 18 Johns. Ch. 110 (N. Y. 1820); Corwith v. Barry, 69 Hun 113 (N. Y. 1S93); see Emigrant Indust. Sav. Bank: v. Van Bokkelen, 269 N. Y. 110, 115, 199 N. E. 23, 25 (1935) ; Lansing v. Godet, 9 Cow. 346,402 (N. Y. 1827) ; Brown v. Frost, 10 Paige 243, 246 (N. Y. 1843); Federal Title \& Mtge. Guar. Co. v. Lowenstein, 113 N. J. Eq. 200, 203, 166 Atl. 538, 540 (Ch. 1933); Stanley, Effect of Economic Depression on Forcilosture (1939) 27 Kr. L. J. 365, 380. An order of resale, when appropriate, is often granted only on assurance of a higher price and security for expenses. Farmers Loan \& Trust Co. v. B. \& M. T. Co., 11y N. Y. 15, 23, 23 N. E. 173, 174 (1890); Wright v. Caprarella, supra; Collins v. Dunston, 59 App. Div. 626, 69 N. Y. Supp. 1132 (4th Dep't 1901); German-American Bank v. Dorthy, 39 App. Div. 166, 57 N. Y. Supp. 172 (4th Dep't 1899) ; Halliday v. Greenke-Halliday Co., N. Y. L. J., June 2, 1932, p. 3094, col. 6 (Sup. Ct.) ; Syracuse Trust Co. v. Corcy, 167 Miisc. $506,513,4$ N. Y. S. (2d) $349,355-56$ (Sup. Ct. 1938); see (1933) 33 CuL. L. REv. 744, 745, n. 9; Note (1933) 85 A. L. R. 1480, 1481 et seq.

21. Graffam v. Burgess, 117 U. S. 180 (1885); see Mratter of Superintendent of Banks, 207 N. Y. 11, 16, 100 N. E. 428,429 (1912) ; Tripp v. Cook, 26 Wend. 143, 153 (N. Y. 1841); Durfee \& Doddridge, Redemption from Foreclosure Salc (1925) 23 MICH. L. REv. 825, 833; Stanley, supra note 20, at 381 et seq.; Colsen and Simpson, The Sale Technique in Corporate Reorganization (1939) 16 N. Y. T. L. Q. Rev. 341, 345 et seq.; (1934) 19 CoRN L. Q. 316,317 at seq.; (1933) 42 Y.LLE L. J. 960, 961; (192i) 27 MICH. L. Rev. 822 ; Note (1920) \& A. L. R. 1001, 1002.

22. Chapman v. Boetcher, 27 Hun 606 (N. Y. 1882); Ames v. Lockwood, 13 How. Pr. 555 (N. Y. 1856) ; see Home Bldg. \& Loan Ass"n v. Blaisdell, 290 U. S. 398, 446, SS A. L. R. 1481, 1519 (1933), and cases cited supra notes 20 and 21; but of. cases cited infra note 25.

23. Haines v. Twelfth Ward Bank, 162 App. Div. 164, 147 N. Y. Supp. 254 (1st Dep't 1914), aff'd, 220 N. Y. 751, 116 N. E. 1049 (1917); Schultz v. MIead, \& N. Y. Supp. 663 (1890), aff'd, 128 N. Y. 680, 29 N. E. 149 (1891) ; see 3 Jones, MozTunGes (\$th ed. 1928) §2206; de Funiak, Right to a Deficiency Judgment (1939) 27 KY. L. J. 410; Note (1938) 117 A. L. R. 863.

24. Durfee \& Doddridge, supra note 21 , at \$32-33; Hunneoon of Cossussion:ers ort Untforar Laws (1922) 275 ; of. Cravath. Soame Legal Phases of Curruzute Finaitiing, Reorganizatiox and Regulation (1930) 204. 
that fully revealed the complete breakdown of the foreclosure machinery ${ }^{20}$ as a protection against unconscionable deficiency judgments, and led the New York lower courts, with some division in their ranks, to make sporadic but ineffectual efforts at amelioration. ${ }^{26}$ But, in general, the established premise that a public sale brought the full value of the property left the courts powerless to deprive the mortgagee of his statutory rights. ${ }^{27}$

Action on the Bond. Before the emergency legislation, a mortgagec could disregard the mortgage and his right to foreclose and recover a judgment for the mortgage debt against the mortgagor ${ }^{28}$ (despite a

25. Twenty-eight of thirty-one parcels sold at foreclosure in New Jersey on the same day brought $\$ 100$ each. See Federal Title \& Mtge. Guar. Co. v. Lowenstein, 113 N. J. Eq. 200, 202, 166 Atl. 538, 539 (Ch. 1933), (1934) 19 Conn. L. Q. 316. See Chemical Bank \& Trust Co. v. Schumann Associates, Inc., 150 Misc. 221, 268 N. Y. Supp. 674 (Sup. Ct. 1934) ; Brabner-Smith, supra note 1, at 722-24. New York courts refused to vacate deficiency judgments recovered on the basis of such bids. Irving Trust Co. v. Edson, N. Y. L. J., Feb. 20, 1933, p. 1033, col. 4 (Sup. Ct.) ; Railroad Cooperative Bldg. \& Loan Ass'n v. Cocks, N. Y. L. J., Feb. 10, 1937, p. 720, col. 5 (Sup. Ct.).

26. Bank of Manhattan Trust Co. v. Ellda Corp., 147 Misc. 374, 265 N. Y. Supp. 115 (Sup. Ct. 1933) (sale postponed until assurance of normal bidding); Central Hanover Bank \& Trust Co. v. Adler, N. Y. L. J., July 29, 1933, p. 343, col. 3 (Sup. Ct.) (sale postponed until end of legislative session); N. Y. Life Ins. Co. v. H. \& J. Guttag Corp., N. Y. L. J., Aug. 1, 1933, p. 370, col. 1 (ibid.) ; McCall v. Maxwell Park Corp., N. Y. L. J., Aug. 1, 1933, p. 370, col. 2 (Sup Ct.) (ibid.) ; Brown v. Wardsview Realties Corp., N. Y. L. J., Aug. 3, 1933, p. 395, col. 3 (Sup. Ct.) (ibid.); Bank of Manhattan Trust Co. v. 2166 Broadway Corp., N. Y. L. J., July 7, 1933, p. 67, col. 1 (Sup. Ct.) (sale adjourned one month); Tishka v. Wisnieska, N. Y. L. J., July 10, 1933, p. 103, col. 6 (County Ct.) (sale adjourned six months); Equitable Life Assur. Soc. v, 2727 Broadway Co., N. Y. L. J., Jan. 27, 1934, p. 441, col. 5 (Sup. Ct.) (sale adjourned nine weeks) ; Farmers \& Mechanics Sav. Bank v. Eagle Bldg. Co., 151 Misc. 249, 271 N. Y. Supp. 306 (Sup. Ct. 1934) (fixes upset price) ; N. Y. Life Ins. Co. v. Johar Realty Co., N. Y. L. J., July 22, 1933, p. 259, col. 3 (Sup. Ct.) (mortgagee delayed sale thirteen months; value of property to be applied on debt) ; Strochak v. Glass Paper Making Supplies Co., N. Y. L. J., May 9, 1933, p. 2794, col. 3 (Sup. Ct.); Id., May 10, 1933, p. 2818, col. 6 (Sup. Ct.) (stays sale), rev'd, 239 App. Div. 312, 267 N. Y. Supp. 282 (1st Dep't 1933) ; Dime Sav. Bank v. Danley Realty Co., N. Y. L. J., June 27, 1933, p. 3839, col. 1 (Sup. Ct.) (refuses to stay sale); Loma Holding Co. v. Cripple Bush Realty Co., 147 Misc. 655, 265 N. Y. Supp. 125 (Sup. Ct. 1933) (refuses to stay action on bond); see (1933) 42 Yale L. J. 960; (1934) 34 Col. L. Rev. 706, 707, n. 13; Gilligan \& Stern, Protecting the Rights of Mortgagors, N. Y. L. J., Aug. 29, 1933, p. 688, col. 1; Id. Aut. 30, 1933, p. 702, col. 1; Notes (1934) 90 A. L. R. 1330, (1933) 82 A. L. R. 976; Perlman, Mortgage Deficiency Judgments During An Economic Depression (1934) 20 VA. L. REv. 771, 805 et seq. Cf. note 152 infra.

27. But it should be noted that judicial reluctance to vacate foreclosure sales had at least the merit of lending stability to judicial titles.

28. General Investment Co. v. Interborough Rapid Transit Co., 200 App. Div. 794, 193 N. Y. Supp. 903 (1st Dep't 1922), aff'd, 235 N. Y. 133, 139 N. E. 216 (1923); sec Kress v. Central Trust Co., 246 App. Div. 76, 78, 283 N. Y. Supp. 467, 469 (4th Dep't 1935), aff'd, 272 N. Y. 629, 5 N. E. (2d) 365 (1936); Schenectady Sav. Bank v. Ashton, 
conveyance), ${ }^{29}$ an assuming grantee, ${ }^{30}$ a guarantor or against all of them. ${ }^{31}$ This right was unaffected by destruction of the mortgage lien through paramount foreclosure, ${ }^{32}$ condemnation $^{33}$ or tax sale. ${ }^{34}$

Before the enactment of statutes making available a deficiency judgment in a foreclosure proceeding, the mortgagee could proceed at law on the bond and foreclose his mortgage in equity concurrently. ${ }^{35}$ This procedure, however, was changed by a series of statutes consolidating the mortgagee's remedies into two complete ${ }^{30}$ but separate actions: he might either proceed on the bond or sue to foreclose. To avoid double litigation and costs the consolidation statutes thus sought to confine all issues to one of two actions and require where possible the joinder of all persons liable on the mortgage. ${ }^{37}$ Foreclosure became a plenary proceeding - in rem to enforce the lien and in personam for a resulting deficiency, the complaint being deemed to state but a single cause of action. ${ }^{38}$ All persons liable for the debt could thus be joined in fore-

120 Misc. 268, 198 N. Y. Supp. 198 (Sup. Ct. 1923), rec'd, 205 App. Div. 781, 783, 200 N. Y. Supp. 245, 247 (3d Dep't 1923).

29. See Johnson v. Zink, 51 N. Y. 333, 336 (1S73); Marshall v. Davies, 78 N. Y. 414, 421 (1879) ; Roch. Sav. Bank v. Stoeltzen \& Tappen, Inc, 176 Mlisc. 140, 26 N. Y. S. (2d) 713 (Sup. Ct. 1941).

30. Burr v. Beers, 24 N. Y. 178 (1861). For the qualifications of the mortgagee's rights against an assuming grantee see Friedman, The Creation and Effet of Personal Liability on MIortgage Debts in New York (1940) 50 Y.LLE L. J. 224, 220 et seq.

31. See Shipman v. Niles, 75 App. Div. 451, 453-54, 78 N. Y. Supp. 440, 441 (1st Dep't 1902), aff'd, 177 N. Y. 527, 69 N. E. 1132 (1903); Roch. Sav. Bank v. Stodizen \& Tappen, Inc., 176 Misc. 140, 26 N. Y. S. (2d) 713 (Sup. Ct. 1941).

32. Frank v. Davis, 135 N. Y. 275,31 N. E. 1100 (1892); Sautter v. Fricls, 229 App. Div. 345, 242 N. Y. Supp. 369 (4th Dep't 1930), aff'd, 256 N. Y. 535, 177 N. E. 129 (1931) ; Weisel v. Hagdahl Realty Co., 241 App. Div. 314, 271 N. Y. Supp. 629 (2d Dep't 1934), 48 Harv. L. Rev. 126.

33. See Hill v. Wine, 35 App. Div. 520, 523, 54 N. Y. Supp. 892,894 (1st Dep't 1898).

34. McRae v. Hummel, 250 App. Div. 873, 295 N. Y. Supp. 202 (2d Dep't 1937).

35. Dunkley v. Van Buren, 3 Johns. Ch. 330 (N. Y. 181S); Jones v. Conde, 6 Johns. Ch. 77 (N. Y. 1822) ; see Jamaica Sav. Bank v. M. S. Investing Co., 274 N. Y. 215, 218, 8 N. E. (2d) 493, 494, 112 A. L. R. 1485, 1492 (1937); Palmer v. Harris, 100 Ill. 276, 280 (1881). This was said to be common practice. Engle v. Underhill, 3 Edw. Ch. 250, 251 (N. Y. 1838).

36. But see National City Bank v. Gelfert, 284 N. Y. 13, 22, 29 N. E. (2d) 449, $453(1940)$.

37. Reichert v. Stilwell, 172 N. Y. 83, 64 N. E. 790 (1902); Grosvenor v. Day, 1 Clarke Ch. 109 (N. Y. 1839); Robert v. Kidanshy, 111 App. Div. 475, 97 N. Y. Supp. 913 (1st Dep't 1906), aff'd, 188 N. Y. 63S, 81 N.E. 1174 (1907) ; Darmstadt v. Manson, 144 App. Div. 249, 128 N. Y. Supp. 992 (2d Dep't 1911); Carlin v. Lindvert, 175 Agp. Div. 940, 161 N. Y. Supp. 1120 (2d Dep't 1916).

38. The deficiency judgment is deemed incidental to the forelosure rather than as stating a separate cause. See Jamaica Sav. Bank v. M. S. Investing Co., 274 X. I. 215, 219, 8 N. E. (2d) 493, 494, 112 A. L. R. 1485, 1489, 1498 (1937); Reichert v. Stilwall, 172 N. Y. $83,88,64$ N. E. 790,792 (1902). 
closure $^{39}$ where a money judgment would be rendered for the residue of the debt left after the sale ${ }^{40}$ and the priority of liability and rightsover settled among the obligors. ${ }^{41}$ As an alternative to foreclosure the mortgagee might maintain an action on the bond, joining all parties personally liable and, after recovery of judgment, levying on the free assets of the obligors. ${ }^{42}$ The two remedies could not, however, be pursued concurrently. ${ }^{43}$ Nor, apparently, could a mortgagee voluntarily discontinue one type of suit for the purpose of instituting the other. ${ }^{44}$ After recovery of judgment in an action on the bond, for example, no foreclosure was maintainable until execution was returned unsatisfied. ${ }^{45}$ Conversely, the institution of foreclosure, where a deficiency judgment was available, debarred the mortgagee from an action on the bond before or after the decree. ${ }^{46}$ Civil Practice Act Section 1078 codified this

39. N. Y. C. P. A. $\$ 1079(7)$.

40. N. Y. C. P. A. $\$ \S 1083,1083-$ a.

41. See Vanderbilt v. Schreyer, 91 N. Y. 392, 397 (1883); Albany Exchange Sav. Bank v. Winne, 168 Misc. 853, 856, 6 N.Y.S. (2d) 699, 702-03 (Sup. Ct. 1938) ; cf. Farnham v. Mallory, 5 Abb. Pr. N. S. 380 (N. Y. 1867).

42. Compare p. 408 infra.

43. Dudley v. Congregation of St. Francis, 138 N. Y. 451, 34 N. E. 281 (1803); White v. Wielandt, 259 App. Div. 676, 20 N. Y. S. (2d) 560 (2d Dep't 1940), aff'd, 30 N. E. (2d) 725 (N. Y. 1941) ; Matter of Whalen, 136 Misc. 296, 240 N. Y. Supp. 587 (Sup. Ct. 1930) (barred from filing involuntary petition in bankruptcy against obligor during pendency of foreclosure); see 3 Jones, Mortanges (8th ed. 1928) \$2206; Tice v. Annin, 2 Johns. Ch. 125 (N. Y. 1816). Contra: Rossbach v. Aurora Holding Corp., 252 App. Div. 842, 300 N. Y. Supp. 601 (1st Dep't 1937) (no opinion); Steitz v. Geiger, N. Y. L. J., July 29,1940 , p. 226 , col. 4 (Sup. Ct.).

44. Engle v. Underhill, 3 Edw. Ch. 250 (N. Y. 1838); but $c f$. Suydam v. Bartle, 9 Paige 294 (N. Y. 1841) (permitted on conditions).

45. N. Y. C. P. A. § 1077. Dudley v. Congregation of St. Francis, 138 N. Y. 451, 457-58, 34 N. E. 281, 282 (1893); Grosvenor v. Day, 1 Clarke Ch. 109 (N. Y. 1839); Guilford v. Crandall, 69 Hun 414, 23 N. Y. Supp. 465 (3d Dep't 1893); Note (1939) 121 A. L. R. 917, 926, 928-29; Scheidell v. Llewellyn Realty Co., 177 N. Y. Supp. 529 (Sup. Ct. 1918) (applied to foreclosure for part of debt theretofore reduced to judgment); cf. Williamson v. Champlin, 8 Paige 70 (N. Y. 1839). During forcclosure no action on the bond is maintainable without cogent reasons. Matter of Moore, 81 Hun 389 (N. Y. 1894). The statute is inapplicable to the subsequent foreclosure of a supplemental mortgage. Reichert v. Stilwell, 172 N. Y. 83, 64 N. E. 790 (1902); see Ferraro v. Marillard Builders, Inc., 227 App. Div. 448, 238 N. Y. Supp. 188 (2d Dep't 1929) (previous action for waste no action on mortgage debt). Cf. note 47 infra.

46. White v. Wielandt, 259 App. Div. 676, 20 N. Y. S. (2d) 560 (1st Dep't 1940), aff'd, 30 N. E. (2d) 725 (N. Y. 1941) ; cf. Honeyman v. Hanan, 275 N. Y. 382, 392, 9 N. E. (2d) 970, 974 (1937), appeal dismissed, 302 U. S. 375 (1937); but cf. President \& Directors of Manhattan Co. v. Callister Bros., 175 Misc. 421, 23 N. Y. S. (2d) 623, aff'd, 260 App. Div. 880, 23 N. Y. S. (2d) 826 (2d Dep't 1940) (mortgage partial security for notes); Schaaf v. O'Brien, 8 Daly 181 (N. Y. Comm. Pl. 1878). But sec Rossbach v. Aurora Holding Corp., 252 App. Div. 842, 300 N. Y. Supp. 601 (1st Dep't 1937) (permits joinder of cause of action for foreclosure with causes for interest and taxes; no opinion); Stitz v. Geiger, N. Y. L. J., July 29, 1940, p. 226, col. 4 (Sup. Ct.) (ibid.). 
limitation by preventing the maintenance of any action for the debt after foreclosure without leave of court. ${ }^{47}$ While the granting of leave was discretionary, the limits of discretion were fairly well marked. It was only granted in special circumstances as, for instance, against a non-resident who had knowledge of the foreclosure and an opportunity to protect his interest at the sale ${ }^{48}$ or where there was another valid excuse for nonjoinder of an obligor. ${ }^{40}$ It was denied if the obligor could have been served ${ }^{50}$ or, if served, no deficiency judgment was sought in the foreclosure, ${ }^{51}$ i.e., where there was no inducement for the obligor to protect his interest at the sale. Again, it was denied in case of some under-

47. N. Y. C. P. A. \$107S. See Duport, Right to Ste on the Bond Bcfore, During and After Foreclosure, N. Y. L. J., May 17, 1932, p. 2748, col. 1, MIay 18, 1932, p. 2772, col. 1. Application for leave should be on notice where the respondent is available for service. Cooper Co. v. Naumberg, 154 App. Div. 225, 138 N. Y. Supp. 1005 (2d Dep't 1912). But it may be given ntme pro tunc in the law action. MeKernan v. Robinson, 84 N. Y. 105 (1881) ; Matter of Corin, 217 App. Div. 809, 217 N. Y. Supp. 908 (3d Dep't 1926) ; Earl v. David, 20 Hun 527 (N. Y. 1880). After reduetion of the mortgage debt to judgment no leave is required in actions to enforce the judgment. Prisco \& Soveris, Inc. v. Service Bond \& IItge Co., 230 App. Div. 713, 242 N. Y. Supp. 897 (2d Dep't 1930) (setting aside a fraudulent transfer); cf. cases supra note 45; Mratter of Gray, N. Y. L. J., MFay S, 1937, p. 2327, col. 7 (Sup. Ct.) (judgment against exeeutor binds legatee by privity; leave unnecessary to enforce judgment at least with respect to executor's undistributed assets); but see Rowley v. Nellis, 41 Misc. 315, $\$ 4$ N. X. Supp. S41 (Sup. Ct. 1903) (no privity between executor and heir); Burnham v. Burnham, 27 Misc. 106 (Sup. Ct. 1899), aff'd. 46 App. Div. 513 (1900), aff'd, 165 N. Y. 659 (1901); Platt v. Platt, 105 N. Y. $48 S$ (1887) (judgment against executor not even frivia foric evidence of debt against heir or devisee).

A claim against a mortgagor's estate was permitted without leave after a foreclosure against an absentee mortgagor. In re Oster's Estate, 8 N.Y.S. (2d) 249 (Surr. Ct. 1938), aff'd, 258 App. Div. 930, 16 N. Y.S. (2d) 612 (4th Dep't 1939). Despite the possibly proper basis for an application here the dispensation with leave is out of line with cases cited supra note 46 and infra note 51 .

48. Matter of Corin, 217 App. Div. S09, 217 N. Y. Supp. 908 (3d Dep't 1926).

49. MrKernan v. Robinson, S4 N. Y. 105 (1881); Guaranty Trust Co. v. Grabowitzky, N. Y. L. J., Sept. 23, 1936, p. 811, col. 3 (Sup. Ct.).

50. Robert v. Kidansky, 111 App. Div. 475, 97 N. Y. Supp. 913 (1st Dep't 1906), aff'd. 188 N. Y. 638, S1 N. E. 1174 (1907) ; Mlatter of Byrne, 81 App. Div. 74, 80 N. Y. Supp. 977 (1st Dep't 1903) ; Mratter of Collins, 17 Hun 289 (N. Y. 1879); see Hochstein v. Schlanger, 150 App. Div. 124, 134 N. Y. Supp. 704 (1st Dep't 1912), aff'd, 208 N. Y. 513, 101 N. E. 1105 (1913); but see Campbell v. Smith, 71 N. Y. 26 (1877).

51. Carlin v. Iindveit, 175 App. Div. 940, 161 N. Y. Supp. 1120 (2d Dep't 1916); Matter of Steiner v. Day, 161 App. Div. 742, 147 N. Y. Supp. 200 (2d Dep't 1914); Morrison v. Slater, 128 App. Div. 467, 112 N. Y. Supp. 855 (1st Dep't 1908); Matter of Marshall, 53 App. Div. 136, 65 N. Y. Supp. 760 (1st Dep't 1900) ; Rowley v. Nellis, 41 Misc. 315, 84 N. Y. Supp. 841 (Sup. Ct. 1903) ; but of. Afatter of MeLaughlin v. Durr, 76 App. Div. 75, 78 N. Y. Supp. 798 (1st Dep't 1902) (supervening paramount foreclosure); Lockwood v. Fawcett, 17 Hun 146 (N. Y. 1879) (foreclosure complaint asked deficiency judgment but no adjudication of liability; may not enforce payment of deficiency out of realty devised by mortgagor); but cf. note 47 supro. 
standing not to seek a deficiency judgment, ${ }^{52}$ or in case of laches ${ }^{63}$ or delay whereby the party to be charged lost a right-over against a person primarily liable. ${ }^{54}$ It has never been denied solely on the ground of an inadequate bid at foreclosure, but neither this factor nor other equities escaped consideration in the cases denying leave. ${ }^{55}$

Death of the Obligor. As a result of statutes overruling the common law, the death of the mortgagor effected substantial changes in the remedies of the mortgagee. Under common law, all charges against realty for which a decedent was liable, including mortgages, became debts of his estate and payable by the personal representative unless the will directed otherwise. ${ }^{56}$ The heir or devisee took the property, as against the representative, free and clear of the mortgage. But popular belief that the rtile was otherwise, i.e., that the mortgaged premises were primarily liable for the payment of the debt, defeated the intentions of testators so frequently that the legislature enacted a statute early in the nineteenth century (now Real Property Law Section 250) reversing the common

52. Scofield v. Doscher, 72 N. Y. 491 (1878); Matter of Marshall, 53 App. Div. 136, 65 N. Y. Supp. 760 (1st Dep't 1900); cf. Wetherell v. Kelly, 195 App. Div. 227, 187 N. Y. Supp. 43 (2d Dep't 1921).

53. Stehl v. Uris, 210 App. Div, 444, 206 N. Y. Supp. 296 (1st Dep't 1924); U. S. Life Ins. Co. v. Poillon, 55 Hun 606, 7 N. Y. Supp. 834 (Sup. Ct. 1889).

54. Matter of Collins, 17 Hun 289 (N. Y. 1879).

55. Leave was unnecessary under Section 1078 after foreclosure by advertisement if a money judgment was unavailable [see Bush v. Robbins, 23 Wkly. Dig. 405 (N. Y. Sup. Ct. 1886); Cape Cod Sav. Bank v. Patton, N. Y. L. J., Apr. 11, 1939, p. 1659, col. 1 (Sup. Ct.)], or in bringing an action based upon a previous deficiency judgment [see Schultz v. Mead, 8 N. Y. Supp 663 (Sup. Ct. 1890), aff'd, 128 N. Y. 680, 29 N. E. 149 (1891); cf. note 47 supra]. It is applicable only to a holder of the mortgage and cloes not affect the right of an obligor who has paid the debt to reimbursement against a primary or co-obligor. As to a primary obligor, see Comstock v. Drohan, 71 N. Y. 9 (1877) ; cf. Hyde v. Miller, 45 App. Div. 396, 60 N. Y. Supp. 974 (4th Dep't 1899), aff'd, 168 N. Y. 590, 60 N. E. 1113 (1901). As to a co-obligor, sec Weed v. Calkins, 24 Hun 582 (N. Y. 1881).

56. See Matter of Burrows, 283 N. Y. 540, 544, 29 N. E. (2d) 77, 79 (1940); Matter of Noyes, 3 Dem. 369, 370 (N. Y. 1885); Notes (1906) 3 L. R. A. (N.s.) 898-99; (1920) 5 A. L. R. 488, 497; (1931) 72 A. L. R. 709; (1939) 120 A. L. R. 577. One reason advanced for the doctrine is that the personalty of the testator was saved from depletion by the giving of the mortgage [see Matter of Fogarty, 165 Misc. 78, 79, 300 N. Y. Supp. 231, 234 (Surr. Ct. 1937)], a reason of doubtful validity when applied to purchase money mortgages where the personal estate of the testator reccived no addition thereby. See Cleaveland, Hewitt \& Clark, Probate law \& Practice of Conn. (1915) $\$ 460 ; 5$ A. L. R. supra, at 505 . The rule is unaffected by a devise expressly subject to the mortgage, which is deemed to describe the premises, or of the testator's interest in the premises, which is deemed to refer to a dower interest surviving the devise 3 L. R. A. (N.S.) supra, at 902 . It is not applied, however, where it would defeat specific bequests. Rice v. Harbeson, 63 N. Y. 493 (1875); see 3 L. R. A. (N.S.) supra, at 902. 
law rule. ${ }^{57}$ This statute required the heir or devisee of property mortgaged by the decedent, in the absence of contrary testamentary directions, to "satisfy and discharge such mortgage out of his own property," without resorting to the representative. The statute was held to cover mortgages assumed as well as executed by the decedent. ${ }^{63}$ And it was not overruled by a general testamentary direction to pay debts. ${ }^{53}$

Section 250 was limited in its terms to the relations between heir or devisee and the general estate, but it was nevertheless extended by construction to the mortgagee. ${ }^{60}$ Though not intended to deprive the mortgagee of any part of his debt, it was held to make the mortgaged premises primarily liable for the mortgage debt and to limit the liability of the representative and distributees of the estate to a deficiency judgment. By judicial legislation, therefore, the mortgagee was required first to foreclose and then to claim against the general estate only for the deficiency. ${ }^{61}$ The mortgagee could not waive his lien on the property and claim for the full amount of his debt against the representative; $; 2$

57. 1 N. Y. Rev. Stat. (2d ed. 1836) p. 740, \$4. See Mfatter of Burrows, 283 N. Y. $540,544,29$ N. E. (2d) 77,79 (1940).

58. Matter of Fogarty, 165 Misc. 78, 300 N. Y. Supp. 231 (Surr. Ct. 1937); Wicts v. Carmichael, 172 Misc. 924, 16 N. Y. S. (2d) 395 (Sup. Ct. 1939).

59. Mreyer v. Cahen, 111 N. Y. 270,18 N. E. 852 (18s2); In re Dell's Estate, 154 Misc. 216, 276 N. Y. Supp. 960 (Surr. Ct. 1935). The delivery of collateral security to the mortgagee by the testator during his lifetime overrules the statute pro tanto. Mlatter of Vicinus, 159 Misc. 903, 290 N. Y. Supp. 20 (Surr. Ct. 1936). A comparable English statute is construed generally to similar effect. 2 Coore, MostG.ages (Sth ed. 1912) 792800. As originally enacted, it included no charges other than mortgages, and the general estate, therefore, remained liable for all other debts affecting the mortgaged premises. See Wright v. Holbrook, 32 N. Y. 587 (1865) (vendor's lien); Mratter of Eabcods, 115 N. Y. 450,22 N. E. 263 (18S9) (taxes); Taylor v. Taylor, 3 Bradi. 5t (N. Y. 1854) (liens for improvements); Lamport v. Beeman, 34 Barb. Ch. 239 (N. Y. 1861); Matter of Hun, 144 N. Y. 472, 476, 39 N. E. 376, 377 (1895). But in 1937 the statute was amended to make the heir or devisee take subject to liens for unpaid purchase price or other charges. N. Y. Laws 1937, c. 75; Matter of Pinkney, 170 Misc. 645, 12 N. Y. S. (2d) 69, aff'd, 257 App. Div. 862,12 N. Y. S. (2d) 824 (2d Dep't 1939) (real estate taxes).

60. See Matter of Weissman, 140 Misc. 360, 361, 250 N. Y. Supp. 500, 501 (Surr. C. 1931).

61. Hauselt v. Patterson, 124 N. Y. 349, 26 N. E. 937 (1891); Mfatter of Rosenbaum, 157 Jisc. 316, 283 N. Y. Supp. 519 (Surr. Ct. 1935); Matter of Perlins, 122 Misc. 593, 204 N. Y. Supp. 667 (Surr. Ct. 1924); see cases cited in Doyle v. Graves, 172 MFisc \$38, 840, 16 N. Y. S. (2d) 554, 556 (Sup. Ct. 1939); but cf. Roosevelt v. Carpenter, 28 Barb. Ch. 426 (N. Y. 1858).

62. Niatter of Burrows, 167 Misc 1, 3 N. Y. S. (2d) 449 (Surr. Ct. 1938), sccond appeal sub nom. Matter of Nichols, 258 App. Div. 807, 15 N. Y. S. (2d) 956 (2d Dep't 1939), rev'd on other grounds sub nom. Matter of Burrows, 283 N. Y. 540, 29 N. E. (2d) 77 (1940) ; but see Prime v. Nichols, 252 App. Div. 446, 447, 299 N. Y. Supp. 629, 630 (2d Dep't 1937) ; Roosevelt v. Carpenter, 28 Barb. Ch. $426,429-30$ (N. Y. 1858). A 
Section 250, on the other hand, created no personal liability in the heir or devisee for the debt. ${ }^{63}$ Thus the mortgagee could recover a judgment against neither for principal or for interest. ${ }^{04}$ For interest accruing before the obligor's death, the mortgagee could recover directly against the representative, ${ }^{65}$ but for interest accruing subsequently it was necessary first to resort to foreclosure and only charge the representative with any resulting deficiency. ${ }^{68}$ Enacted for the purpose of preventing an heir or devisee from taking property, as against the representative, free and clear of the mortgage, ${ }^{67}$ Section 250 thus construed had the further effect of marshalling the assets by postponing and qualifying the mortgagee's rights on the bond. ${ }^{68}$ The mortgagee, however, was afforded some protection against dissemination of assets properly applicable to payment of his deficiency by a statute empowering the surrogate, on the mortgagee's application as a contingent creditor, to direct reservation

literal reading of the statute does not preclude a claim against the estate where the property was sold during the mortgagor's lifetime because it refers only to property which "descends to an heir, or passes to a devisee." The temper of the decisions; however, makes it questionable whether such construction would be upheld. Cf. Matter of Reilly, 175 Misc. 597, 24 N. Y. S. (2d) 213 (Surr. Ct. 1940), (1941) 54 HARv. L. REv. 1067; Matter of Bernard, 176 Misc. 132, 26 N. Y. S. (2d) 767 (Surr. Ct. 1941).

63. Hauselt v. Patterson, 124 N. Y. 349,26 N. E. 937 (1891) (but heir liable for value of aliened lands); Doyle v. Graves, 172 Misc. 838,16 N. Y. S. (2d) 554 (Sup. Ct. 1939). This should be distinguished, however, from the right of an estate creditor to follow assets into the hands of beneficiaries. See note 69 infra.

64. Bank of N. Y. Trust Co. v. Marsh, N. Y. L. J., May 29, 1940, p. 2449, col. 2 (Sup. Ct.), aff'd withont opinion, 260 App. Div. 1013, 24 N. Y. S. (2d) 1607 (1st Dep't 1940), aff'd, 285 N. Y. 813, 35 N. E. (2d) 197 (1941); Doyle v. Graves, 172 Misc. 838, 16 N. Y. S. (2d) 554 (Sup. Ct. 1939).

65. New Rochelle Trust Co. v. Hinton, 256 App. Div. 724, 11 N. Y. S. (2d) 7(17 (2d Dep't 1939), aff'g, 9 N. Y. S. (2d) 861 (Sup. Ct. 1938). The representative is credited for such payments on his accounting. Matter of Soper, 224 App. Div. 431, 231 N. Y. Supp. 333 (4th Dep't 1928) ; Matter of Rosenstein, 152 Misc. 777, 782, 274 N. Y. Supp. 126, 131-32 (Surr. Ct. 1934). Where the mortgaged premises are left in trust interest accrued to death is payable from interest while interest thereafter accruing is payable from income. Matter of Stiles, 64 Misc. 658, 120 N. Y. Supp. 714 (Surr. Ct. 1909).

66. Levy v. Comfort, 13 N.Y.S. (2d) 845 (County Ct. 1939), aff'd, 257 App. Div. 1037, 13 N.Y.S. (2d) 847 (4th Dep't 1939); see cases cited supra note 64. A representative who pays such interest receives no credit therefor on his accounting. Matter of Soper, 224 App. Div. 431, 231 N. Y. Supp. 333 (4th Dep't 1928); Matter of Watson, 101 App. Div. 550, 92 N. Y. Supp. 195 (1st Dep't 1905) ; Matter of Hackert, 171 Misc. 139, 11 N. Y. S. (2d) 987 (Surr. Ct. 1939) ; Matter of Fogarty, 165 Misc. 78, 300 N. Y. Supp. 231 (Surr. Ct. 1937) ; Matter of Roberts, 72 Misc. 625, 132 N. Y. Supp. 396 (Surr. Ct. 1911).

67. See Wright v. Holbrook, 32 N. Y. $587,589-90$ (1865) ; Roosevelt v. Carpenter, 28 Barb. Ch. 426, 429 (N. Y. 1858).

68. See dissenting opinion in New Rochelle Trust Co. v. Hinton, 256 App. Div. 724, 726, 11 N. Y. S. (2d) 707, 709 (2d Dep't 1939). 
of assets deemed sufficient to pay a deficiency judgment when finally determined. ${ }^{69}$

\section{Eurergency and Subsenuext Legisl.ition}

Deficiency Judgments. Beginning in 1933 the remedies of the mortgagee were substantially changed by a series of state statutes. At that

69. N. Y. SURR. CT. ACT \$207. Mfatter of Burrows, 283 N. Y. 540, 29 N. E. (2d) 77 (1940). The Burrows case implies that the reservation must lie equal to the full principal of the mortgage debt. Before this decision the surrugaten were estremely relustant to reserve assets indefinitely for the protection of a mortgagee's contingent elaim. Generally, they found the value of the mortgaged premises high enough to warrant dictribution of other assets. See Matter of Reilly, 175 Misc. 597, 601-02, 604, 24 N. Y. S, (2d) 213, 217-18, 220 (Surr. Ct. 1940), (1941) 54 Haks. L. Rw. 1067, 10ts. Since the Burrow's decision, however, an amendment to N. Y. SrRr. Cr. ACT \&207 (N. Y. Law: 1941, c 86) authorizes the surrogate to alpraise the value of the creditor's security and reserve assets equal to the deficit. The amendment proliably reinstates the practice of the lower courts.

The mortgagee may require an accounting of the representative before distrilution. Rositzke v. Meyer, 176 App. Div. 193, 162 N. Y. Supp. (113 (21 Dep't 1916); and may join him in foreclosure for the purpose of recovering a deficiency jurlgment [Glacius $v$. Fogel, 88 N. Y. 434 (1882); Kings Cty. Trust Co. v. Derx, 237 Arp. Div. $548,261 \mathrm{~N}$. Y. Supp. 909 (2d Dep't 1933)], which thereupon becomes a debt payable out of the estate with others of the same class. But if the representative has theretofore mads a proper distribution, he is not subject to account or surcharge for the benefit of the mortgagee. Matter of Fransinett, 175 Misc. 52, 22 N. Y. S. (2d) 718 (Surr. Ct. 19:0), aff'd, 260 App. Div. 997, 24 N. Y. S. (2d) 985 (1st Dep't 1940); Matter of Dusenbery v. Bragg, 241 App. Div. 553, 273 N. Y. Supp. 1 (4th Dep't 1934); In re Coston, 172 Mise. 494, 15 N. Y. S. (2d) 870 (Surr. Ct. 1939). But the mortgagee may, nevertheless, in a creditor's action, follow estate assets into the hands of the beneficiaries, a right independent of statute, but regulated under N. Y. DEC. Esr. L.w $\$ 170$ et seq. Colgan $v$ Dunne, 50 Hun 443, 3 N. Y. Supp. 309 (18SS) ; Erooklyn Sav. Eank v. Joseph Wechsler Estate, 259 N. Y. 9, 180 N. E. 752 (1932). This involves practical difficulties because of the rules of marshalling assets or rather, in this case, of marshalling liability [see Lawrence v. Grout, 112 App. Div. 241, 7S N. Y. Supp. 279 (1st Dep't 1906)], the possible location of beneficiaries beyond the jurisdiction, and the fragmentation of assets effected by distribution. Often, distribution occurs before the mortgagee ean reduce his claim to judgment, as, e.g., where the mortgage is not due at the mortgagor's death, where the mortgagor sold the premises during his lifetime, or where for other reasons the representative may be unaware of the claim or the mortgagee of the mortgagor's death.

Presumably, the purpose of recovering a deficiency judgment against the representative, after distribution of the estate, is to predicate a subsequent creditor's action. Mlatter of Dusenbery v. Bragg, supra; Matter of Perkins, 122 Mise. 593, 204 N. Y. Supp. 667 (Surr. Ct. 1924). The mortgagee's right to recover a deficiency judgment against estate beneficiaries in a foreclosure action is apparently in conflict. The right was upheld in Olmstead v. Latimer, 158 N. Y. 313, 53 N. E. 5 (1899); Collins' Petition, 6 Abb. N. C. 227 (N. Y. 1879) ; First Nat. Bank v. Goodman, 173 Xfisc. 562, 1S N. Y. S. (2d) 562 (Sup. Ct. 1940) (and cases there cited); but denied in Leonard v. Morris, 9 Paige 90 (N. Y. 1841) ; Buckley v. Beaver, 99 Misc. 643, 160 N. Y. Supp. 131 (Sup. Ct. 1917). Cf. 1 Wiltsie, Mortgage Forectosures (5th ed. 1939) $\$ \$ 416$, 417. These cases hardly 
time the New York Legislature, like many others, ${ }^{70}$ recognized the existence of a "serious public emergency . . . abnormal disruption in economic and financial processes, the abnormal deflation of real property values and the curtailment of income by unemployment. . . ."71 Its response was an elaborate group of statutes designed to cope with the situation in two general ways. First, foreclosure ${ }^{72}$ and actions on the bond ${ }^{73}$ for non-payment of principal were barred if interest and taxes were paid - a phase irrelevant to this article. Secondly, Civil Practice Act Section 1083-a sought to bar recovery of money judgments in excessive amounts by limiting deficiency judgments to the excess of the mortgage debt over the fair value of the property regardless of the actual proceeds of the foreclosure sale. ${ }^{74}$ To prevent the mortgagee from circumventing Section 1083-a by disregarding the mortgage and sting for the debt, Section 1083-b was enacted to permit the obligor to offset the fair value of the property in an action brought on the bond. ${ }^{75}$ The

discuss the problems involved. One is whether beneficiaries subject to jurisdiction mity be joined in foreclosure and their proportionate liabilities fixed, or, if not, whether the mortgagee must obtain special leave in the foreclosure court to bring a subsequent creditor's action, which may involve independent procedural difficulties. See Lawrence v. Grout, supra. Another problem is whether a judgment creditor's action will lic without an adjudication of liability in the foreclosure, which raises the further question of privity between representative and beneficiary. See note 47 stpra. In any event, completion of the foreclosure or ultimate recovery of a money judgment, or probably both, are delayed. National Sav. Bank v. National Commercial Bank \& Trust Co., 176 Misc. 1057, 29 N. Y. S. (2d) 840 (Sup. Ct. 1941), permits joinder of the distributee in foreclosture, (lenies the need for an accounting, and indicates the possibility that liability may be determinted in the foreclosure alone. But this seems practical only when distribution is conplete and the beneficiaries subject to jurisdiction. Cf. Pink v. Keiber, N. Y. L. J., May 8, 1941, p. 2072, col. 1 (Sup. Ct.). This may account for the difference in the cases. If the cone solidation statutes require special leave before subsequent proceclings will lie against the beneficiaries [cf. note 47 stpra], then refusal to permit joinder of beneficiaries in the foreclosure action begins a pyramid of procedural difficulties for the mortgagee.

70. See 128 C. C. H. Fed. Bank Serv. (Loan \& Finance Unit) $\{17501$ (cumulative chart of legislation); 3 Wiltsie, Mortgage Foreclosures (5th cd. 1920) \$977; (1934) 19 CORN. L. Q. 316, 322 et seq.; Keaton, Deficiency Judgments and Decrecs (1934) 20 VA. L. Rev. 743, 765 et seq.; Perlman, Mortgage Deficiency Judgments During an Economic Depression (1934) 20 VA. L. REv. 771-805.

71. N. Y. Laws 1933, c. 794, § 1 .

72. N. Y. C. P. A § 1077-a.

73. N. Y. C. P. A. $\$ 1077-$ b.

74. Thus, where the property on foreclosure is sold to a third party for a lesser amount than the fair value as subsequently determined by the court, the mortgagee must accept as full satisfaction an amount less than the contractual obligation. To avoid the risk of this loss the mortgagee may be compelled to buy in at the sale. But the significance of this result is minimized by the rarity of outside purchasers. See notes 24 and 25 supra.

75. One method of evasion, i.e., by a contract by the mortgagor to bid the amount of the mortgage debt at foreclosure sale, was upheld. Hellawell v. Baer, N. Y. L. J., July 20, 1936, p. 194, col. 2 (Sup. Ct.); but it misfired when the mortgagee's damages for' 
legislation was restricted to mortgages made before July $1,1932,{ }^{70}$ in the belief that emergency laws would be unnecessary to protect mortgages made thereafter in a low market. ${ }^{77}$ July 1,1934 , was originally fixed as the end of the emergency, ${ }^{78}$ but by successive reenactments the period has been extended, the present one expiring July 1, 1943. In 1938 , however, the deficiency judgment provisions were incorporated ints, the permanent law.

Hurried enactment of these statutes deprived them of precise draftsmanship and raised questions subsequently solved only in part by sporadic amendment and construction. Section 1083-a provided that, on application for a deficiency judgment, the obligor be credited with the sale price or the fair value of the property, whichever was higher. Is standards for determining the fair value of the property, the Act prescribed "fair and reasonable market value of the mortgaged premises" as of the date of the sale "or such nearest earlier date as there shall have been any market value thereof." Since the legislation was enacted at a time when the great preponderance of all sales was judicial or otherwise forced, the legislature recognized, for the purpose of determining fair value, the possible necessity of reverting to an earlier period when there was less exclusively a buyer's market. Some courts sought to make current appraisals by scrutinizing the usual elements of value. ${ }^{70}$ Some sought to fix value by the projection of two supposititious creatures the "willing seller" and the "willing buyer." 80 But most courts, influenced by language of the Court of Appeals in its opinion determining the validity of the statute, ${ }^{81}$ found no market in the legislative sense as of the period of the foreclosure and reverted to 1930 or $1931,{ }^{82}$ often

breach were reduced by the value of the property. Id., 249 App. Div. 641, 292 N. X. Supp. 85 (2d Dep't 1936). See generally Wheeler \& Durfee, Ez'asion of Moratoria by Prosecution of Personal Remedics (1935) 33 Mrсm. L. Rev. 1190.

76. N. Y. C. P. A. \$1077-g; Chase Nat. Bank v. Guardian Realties, Inc., 283 N. I. 350, 365, 28 N. E. (2d) 868, $\$ 73$ (1940); Sheepshead Bay Bungalow Co. v. Mandel \& Co., 244 App. Div. \$11, 279 N. Y. Supp. 556 (2d Dep't 1935).

77. Decker v. Dutcher, 247 App. Div. 689, 691, 289 N. Y. Supp. 553, 555 (3d Deg't 1936).

78. N. Y. C. P. A § $1077-g$, (as originally enacted, N. Y. Laws 1933, c. 793).

79. See (1935) 35 CoL. L. Rev. 1314.

80. Berkshire Life Ins. Co. v. Van Voorhis, 245 App. Div. 592, 283 N. Y. Supp. 95 (4th Dep't 1935) ; President \& Directors of Mianhattan Co. v. Premier Bldg. Co., 247 App. Div. 297, 285 N. Y. Supp. 806 (2d Dep't 1936).

81. "There being no market for real estate of any kind, and the banks refusing to loan money on the best of real estate security, owners were caught, as it were, in a trap due to conditions over which no one had control and for which no relief was at hand. Value was in the property but the value could not be obtained nor anything like it." Klinke v. Samuels, 264 N. Y. 144, 149, 190 N. E. 324, 326 (1934).

82. Corn Exchange Bank Trust Co. v. Ekenberg, 101 Mise. 62, 292 N. Y. Supp. 142 (Sup. Ct. 1936) ; Fulton Trust Co. v. Kraft, 155 Misc. 709, 280 N. Y. Supp. 397 (Sup. Ct. 1935), 35 Col. L. Rev. 1314; Central Hanover Bank \& Trust Co. v. Kraft, 
on affidavits alone and without a hearing - a method invariably sealing the fate of the mortgagee. ${ }^{83}$

After three years of application of Section 1083-a by the lower courts the Court of Appeals finally recognized in Heiman v. Bishop ${ }^{84}$ that old standards of market value had become useless and that willing buyers, willing sellers and ordinary conditions had gone by the way. The lower court, finding that there existed no "fair and reasonable matrket value of the premises" as of the date of the sale, denied application for a deficiency judgment because during the nearest earlier period in which it found a market, the value of the property exceeded the debt. The Court of Appeals, however, found that the purpose of Section 1083-a was not to deprive mortgagees of deficiency judgments but rather to establish a new "equitable standard" for determining them. Evidence of value, according to the court, might be found not only in market transactions of real property similarly situated but also by an examination of every relevant element of value apart from the market, including "agc and construction of the buildings on the premises, the rent received therefor, assessed value [for tax purposes], location, condition of repair . . . conditions in the neighborhood which affect the value of the property therein, accessibility," etc. ${ }^{85}$ Thus the court precluded resort to a pre-depression period of high market prices for purposes of determining value unless a non-market appraisal on the basis of the existing condition of the premises were found impossible. ${ }^{80}$ As a rough generalization, it can be said that values so found by the lower courts after the decision in the Heiman case tended to approximate tax assessments. Although deficiency judgments were granted far less frequently than

248 App. Div. 216, 288 N. Y. Supp. 1004 (1st Dep't 1936), rev'd, 273 N. Y. 634, 7 N. E. (2d) 730 (1937). This period was selected because real estate, unlike the stock market, was unaffected by the depression until late in 1931 or early in 1932. See the Ekenberg case, supra at 64, $292 \mathrm{~N}$. Y. Supp. at 144.

83. This method received a check in the Guttag case, holding that when the motion papers present an issue of fact, either party is entitled to trial before the court or referee. N. Y. Life Ins. Co. v. H. \& J. Guttag Co., 265 N. Y. 292, 192 N. E. 481 (1934). The court or referee may not go outside the record and base its conclusion upon an independent view of the premises or other information personally obtained and not subject to cross-examination. Central Hanover Bank \& Trust Co. v. Eisner, 276 N. Y. 121, 11 N. E. (2d) 561 (1937). The report of the referee is not conciusive on the court and the Appellate Division may make its own determination of value on appeal. McCarthy $v$. Jablonski, 253 App. Div. 759 (2d Dep't 1937); Ballin v. Apperson Realty Co., 258 App. Div. 264, 16 N. Y. S. (2d) 251 (1st Dep't 1939), aff'd, 283 N. Y. 754, 28 N. E. (2d) 973 (1940).

84. 272 N. Y. 83,4 N. E. (2d) 944 (1936).

85. Id. at 88,4 N. E. (2d) at $945-46$; cf. In re Bd. of Water Supply, 277 N. Y. 452, 14 N. E. (2d) 789 (1938).

86. Corn Exchange Bank Trust Co. v. Island Park-Long Beach, Inc., 251 App. Div. 857, 298 N. Y. Supp. 496 (2d Dep't 1937), aff'd, 277 N. Y. 565, 13 N. E. (2d) 475 (1938); First Nat. Bank v. Goodman, 173 Misc. 562, 18 N. Y. S. (2d) 562 (Sup. Ct. 1940). 
before the emergency period, Heiman a. Bishor did not, as predicted by one cynic, have the effect of inducing the lower courts, after examining expensive records, invariably to deny applications for deficiencies.

Action on the Bond. Under the emergency legislation, an action still lies on the debt whenever one lies to foreclose a nortgage, ${ }^{57}$ jrovided the personal liability of the debtor has not been released. Section 1083-b, permits the defendant in such an action to "set off the fair and reasonable market value of the mortgaged premises less amounts owing on prior liens and encumbrances." The burden of proving the value "ff the premises lies with the defendant. ${ }^{\text {ss }}$ This "set-off" does nut operate, however, as part payment of the deht or as an ultimate credit in the mortgagor's favor, but merely as a statutory suspensiun of a part of his obligation. Although the mortgagee recovers a judgment only for the difference between the debt and the fair value of the property, he may recover the balance in an in personam action after the expiration of the emergency. ${ }^{59}$ Or after the emergency period he may sue tu foreclose and obtain a deficiency judgment, subject, however, to a credit for the amount previously recovered at law. ${ }^{90}$

If a mortgagee were also a debtor of the mortigagor on a separate obligation, he was not precluded by the muraturium statutes as uriginally enacted from setting off the mortgage debt in an action by the murtgagor on the separate obligation. The statute, it was held, suspended only the right to maintain an action. Thus a banker-mortgagee could deduct the amount of a depositor-mortgagor's accuunt and properly tender a satisfaction piece of the mortgage. ${ }^{91}$ This right of set-off in the mortgagee, predicated on maturity of the debt, was promptly terminated, ${ }^{12}$ however, by the enactment of a statute expressly extending the time of payment of principal until the end of the emergency or thereafter. ${ }^{93}$

S7. Emsig v. Fuchs, 159 Misc. S03, 288 N. Y. Surp. 784 (Sup. Ct. 1936 ).

88. Ibid. An answer alleging the value of the premises cquals the debt presents a triable issue not subject to summary disposition. Gaimari v. Hord, 249 . Alp. Dir. 537, 293 N. Y. Supp. 479 (1st Dep’t 1937) ; Bergman v. Santamaria, 244 AII\%. Div. 819, 27") N. Y. Supp. 876 (2d Dep't 1935).

89. Goldman v. Ginsberg, 247 App. Div. 797, 286 N. Y. Surp. 137 (2d Dep't 1936).

90. N. Y. C. P. A. $\$ 1083-b ;$ Tanico v. Mfule, N. Y. L. J., Des. $2 \$, 1935$, p. 2647, cul. 5 (Sup. Ct.).

91. Kress v. Central Trust Co., 246 App. Div. 76, 283 N. Y. Supp. 467 (4th Dep't 1935), aff'd, 272 N. Y. 629,5 N. E. (2d) 365 (1936), (1935) 48 Husw. L. KEv. 345 ; Matter of Westchester Trust Co., N. Y. L. T., Mar. 24, 1934, p. 1427, col. 5 (Sup. Ct.); see Matter of Vicinus, 159 Misc. $903,290 \mathrm{~N}$. Y. Supp. 20 (Surr. Ct. 1936) (right to retain collateral security); N. Y. Title \& AItge. Co. v. Ining Trust Co., 241 App. Dis. 246, 271 N. Y. Supp. 775 (1st Dep't 1934), aff'd, 268 N. Y. 547, 193 N. E. 397 (1935).

92. In re Prudence Co., 16 F. Supp. 2\$2, 285 (E. D. N. Y. 1936); Mfatter of Fingyht, 162 Mrisc. 942, 296 N. Y. Supp. 506 (Surr. Ct. 1937).

93. N. Y. C. P. A. $\$ 1077-a$, as amended, N. Y. Laws 1934 , c. 35\%. This statute extends some mortgages to the end of the cmergeney, sume for sis munth longur and 
If a foreclosing mortgagee fails to apply for a deficiency judgment within 90 days after the foreclosure sale or if an application is denicel, the proceeds of sale are conclusively deemed to satisfy the mortgage debt, ${ }^{94}$ and the mortgagee is barred from action on the bond..$^{95}$ If, however, the lien of the mortgage has meanwhile been extinguished by paramount foreclosure or tax sale, the obligation is no longer secured by a mortgage or subject to mortgage legislation. If in such a case the obligor could offset value, the amount of offset would represent not a suspension but an annihilation of the mortgagee's rights. Conscquently, if the mortgage is extinguished, the mortgagee may enforce his bond, without an offset for the value of the property, like any other unsecured general creditor. ${ }^{96}$ But except where the mortgage has been extinguished, recovery is limited to the difference between the amount of the obligation and the fair value of the property as determined by the court. The improbability that this amount will be substantial has discouraged mortgagees from undertaking the trouble and expense of litigating actions on the bond. ${ }^{97}$ An action for interest, however, opens up possibilities.

Actions for Interest. In Johnson v. Meyer, ${ }^{08}$ the Court of Appeals permitted a mortgagee to recover judgment for interest and taxes ${ }^{00}$ alone without offset for the value of the premises. The decision of the court, however, raised more questions than it answered. Mindful of the fact that judgments for interest represent but a small fraction of the mortgage debt, mortgagees wondered if recovery would, under Civil Practice Act Section 1077, prejudice a subsequent foreclosure. By its terms the statute did not contemplate an action for part of the debt, and authority

others for one year longer-an apparent effort to taper off the moratorium and onc which is becoming academic through recurrent extensions of the emergency legislation. if. N. Y. C. P. A. §1077-g, as amended, N. Y. Laws 1941 , c. 782.

94. N. Y. C. P. A. \$1083-a. The period begins from the delivery of the referce's deed, not the auction sale. Ibid.

95. Honeyman v. Hanan, 275 N. Y. 382, 9 N. E. (2d) 970 (1937); cf. Roscufeld v. Levine, 249 App. Div. 142, 148, 291 N. Y. Supp. 474, 481 (1st Dep't 1936).

96. Wittwer v. Goldstein, 268 N. Y. 703, 198 N. E. 566 (1935); Weisel v. Hagdahl Realty Co., 241 App. Div. 314, 271 N. Y. Supp. 629 (2d Dep't 1934), 48 Hakv. L. Rev. 126; see p. 387 supra, p. 409 infra.

97. One of the few cases is McKeon v. Britt, N. Y. L. J., June 29,1939 , p. 3003, col. 5 (Sup. Ct.), where the holder of an $\$ 18,000$ mortgage, junior to a first of about $\$ 16,000$, recovered judgment for $\$ 3,707$.

98. 268 N. Y. 701,198 N. E. 565 (1935).

99. Properly speaking, a mortgagee does not sue for taxes. If he pays the tax he may add such advance to the mortgage debt and recover judgment for its reimbursement. This is provided by N. Y. REAL Prop. LAw $\$ 254(6)$, which merely codifies a rule of equity. Mutual Life Ins. Co. v. Newell, 78 Hun 293, 28 N. Y. Supp. 913 (2d Dep't 1894), aff'd, 144 N. Y. 627,39 N. E. 494 (1894) ; Baranowski v. Wetzel, 174 App. Div. 507; 161 N. Y. Supp. 153 (2d Dep't 1916); see 3 Cooley, Taxation (4th ed. 1924) $\$ 1263$. 
for its inapplicability to suits for less than the entire obligation was too tenuous for the careful practitioner. ${ }^{100}$ Furthermore, if the interest in question had accrued subsequently to maturity of the mortgage, the issue arose whether it had become such a part of an indivisible cause of action for the whole obligation that recovery of part would, by splitting a single cause, prevent further legal action by the mortgagee upon either the bond or mortgage.

In Rochester Trust \& Safe Deposit Company a. Hatch, ${ }^{101}$ the Cuurt of Appeals reviewed an action for principal and installments of interest and taxes. The defendant had sought to offset value against all the claims. Without discussion the court affirmed an order striking the defense from all causes except principal, thus holding severable the cause for interest and taxes. The narrow limits of this decision prompted some mortgagees to proceed cautiously by way of declaratory judgment. In a series of subsequent decisions, however, mortgagees were held entitled to recover judgments for taxes and interest, regardless of maturity of principal, without prejudice to the right to maintain actions for installments thereof subsequently accruing. for the principal of the mortgage debt, or for foreclosure. ${ }^{102}$ Declaratory judgments were frequently granted to this effect. ${ }^{103}$

The courts usually advanced two rationales for this result, namely that the parties intended severable causes by fixing separate times of payment for interest and principal, and that the legislative suspension of principal did not in terms postpone interest and taxes. The first reason, however, seems unreliable since the mortgage covenants in issue were

100. Scheidell v. Llewellyn Realty Co., 177 N. Y. Supp. 529 (Sup. Ct. 1918). N. Y. C. P. A. $\$ 1077$ provides: "Where final judgment for the plaintiff has been rendercl in an action to recover any part of the mortgage debt, an action shall not be maintained to foreclose the mortgage, uniess an execution against the property of the defendant has bsen issued . . . and has been returned wholly or partly unsatisfied."

101. 273 N. Y. 507,6 N. E. (2d) 426 (1937).

102. Hecht v. Flatto, 158 Misc. 464, 285 N. Y. Supr. 949 (1st Dep't 19301, off'd, 249) App. Div. 722, 292 N. Y. Supp. 995 (1st Dep't 1936) (actiun against guarantor); Blacl: v. Metropolitan Casualty Ins. Co., 166 Misc. 318, 2 N. Y. S. (2d) 380 (X. Y. City Ct. 1937) (ibid.); Hebrew Children's Home, Inc. v. Walter, los Mise. 117, 5 N. I. S. (2d) $22 S$ (Sup. Ct. 1938) (mortgagor's conveyance no defense); sex cases cited infra note 103 .

103. Union Trust Co. v. Kaplan, 247 App. Div. 588 , 28S N. Y. Supp. $2 \$ 8$ (4th Depit 1936), second appcal, 249 App. Div. 280, 292 N. I. Suyp. 152 (4th Dep't 1936); Westchester Trust Co. v. Estate of Edward Underhill, Inc. N. Y. L. J., Mar. 19, 1938. p. 13.4, col. 3 (Sup. Ct.), aff'd, 255 App. Div. 1013, 9 N. Y.S. (2d) 575 (2d Dep't 1933) ; Bants wi New York v. Blumenthal, N. Y. L. J., Mar. 30, 1940, p. 1445, col. 3 (Sup. Ct.), aff'd, 260 App. Div. 919, 24 N. Y. S. (2d) 151 (1st Dep't 1940), off'd, 33 N. E. (2d) 539 (N. Y. 1941). One court, however, giving such relief against sume defendants, denicd it against others on the technical ground that the latters' failure to challenge the flaintiff's rights avoided the creation of a justiciable controversy. Union Trust Co. v. Simpron, 160 Misc. 836,290 N. Y. Supp. 859 (Sup. Ct. 1936), (1937) 22 Corss. L. Q. 467. 
drawn at a time when separate actions were not seriously contemplated. As for the second ground, it must first be noted that the general limitation on splitting any cause of action was devised for the benefit of debtors $^{\mathbf{1 0 4}}$ to prevent multifariousness and harassment. Since interest accruing after maturity is generally deemed a component part of the debt, permitting these actions by the mortgagee infringes the purpose of the rules against splitting causes by allowing the plaintiff's election to govern defendant's right of set-off. It has been argued accordingly that the legislature never intended such a result. ${ }^{105}$ But legislative intent, always a doubtful matter, ${ }^{106}$ is perhaps evidenced by the legislatturc's failure to override the governor's veto of a series of bills ending separate suits for interest and taxes. ${ }^{107}$ Undoubtedly, a statute forbidding actions for interest would have manifested a clear legislative intent, but such a statute would probably have been invalid insofar as it purported to be retroactive ${ }^{108}$ - a result which would have defeated the purpose of the emergency legislation. This legislation was enacted not to void the mortgagor's obligation but to suspend foreclosure actions for principal if interest and taxes were paid. ${ }^{109}$ It has been suggested that a mortgagee who sues for interest comes within the spirit of the moratorium by avoiding foreclosure ${ }^{110}$ but a more impressive argument is that, regard. less of express "intent", the emergency acts avoid a transgression of legislative power by sanctioning actions for interest and taxes indcpendently of principal. It might be possible, however, to end the maintenance of separate actions by procedural legislation unifying the separate causes $^{111}$ without impairing the mortgagee's substantive rights.

The right to recover interest and taxes independently has been limited to in personam actions against the mortgagor. The lower court in White v. Wielandt ${ }^{112}$ held that a mortgagee, joining causes for interest and

104. Carrington v. Crocker, 37 N. Y. 336 (1867); Mills v. Garrison, 3 Keyes 40 (N. Y. 1866).

105. See (1937) 22 CoRN. L. Q. 407. Linowitz, Suits for Interest Under the N. Y. Moratorium (1940) 25 CORN L. Q. 400, 402, concurs in the statement that the majority rule merges principal and interest after maturity. But cf. cases in Union Trust Co. v. Simpson, 160 Misc. 836, 839, 290 N. Y. Supp. 859, 862 (Sup. Ct. 1936).

106. See Woollcott v. Schubert, 217 N. Y. 212, 221, 111 N. E. 829,831 (1916), ("statements and opinions of legislators uttered in the debates" incompetent as cvidence); Home Bldg. \& Loan Ass'n v. Blaisdell, 290 U. S. 398, 427, 88 A. L. R. 1481, 1489,1519 (1933).

107. See Linowitz, supra note 105, at 409. N. Y. Assembly Intro. No. 1912 (1941).

108. See cases cited infra notes 132, 133, 149.

109. White v. Wielandt, 259 App. Div. 676, 678-79, 20 N. Y. S. (2d) $560,563-64$ (2d Dep't 1940), aff'd, 30 N. E. (2d) 725 (N. Y. 1941).

110. Union Trust Co. v. Kaplan, 249 App. Div. 280, 284, 292 N. Y. Supp. 152, 15? (4th Dep't 1936).

111. Compare Honeyman v. Hanan, 275 N. Y. 382, 9 N. E. (2d) 970 (1937), appeal dismisscd, 302 U. S. 375 (1937).

112. 172 Misc. 686,17 N. Y. S. (2d) 666 (County Ct. 1939). 
taxes with foreclosure, could obtain the usual foreclosure relief for principal and, in addition, an independent money judgment for the full amount of interest and taxes without proof of value under Section 1083-a. The court justified this result on the ground that the Hatch case had held the causes severable. The judgment was reversed, however, by the Appellate Division, Second Department, on the theory that this was a palpable evasion of Section 1083-2..13 The basis uf the reversal was twofold. First, the court held that interest and taxes were such an integral part of the mortgage debt that an action to recover them was not severable from an action of foreclosure for the principal. But this point might not have force if default in payments of interest is not the sole basis for foreclosure. If the cause for interest is not essential to foreclosure, a holding that the actions are inseverable seems to contravene the Hatch case. Secondly, the court was on sounder grounds in holding that the consolidation statutes previously discussed barred the simultaneous maintenance of foreclosure and an action for the debt. ${ }^{114}$ Directly contrary to the IVhite case. however, was the earlier case of Rassbach $v$. Aurora Holding Company. ${ }^{15}$ decided by the Appellate Division, First Department, on the basis of the Hatch case. Hert, too, the same defaults were used as a basis for foreclosure and a money judgment. The decision seems unsound in disregarding the consolidation statutes. ${ }^{116}$

Collateral Security. The emergency mortgage laws make no express provision for the disposition of collateral given to the mortgasee as security for payment of the debt. Such security may consist of rents to be collected by foreclosure receivers, collateral bonds, claims for tax refunds, claims for proceeds of fire insurance, chattel or supplemental real property mortgages, or securities delivered to the mortgagee.

Civil Practice Act Section 1083-a provided that in the alssence of an application for a deficiency judgment, or in the event of its denial, the proceeds of the foreclosure sale should be conclusively deemed to satisfy the mortgage debt and no action lay for the deficit. As sun as this statute became effective, however, a question arose as to whether a mortgagee was entitled to the receiver's rents without having recovered a

113. 259 App. Div. 676, 20 N. Y. S. (2d) $5(00$ (2d Dep't 1910), aff'd, 30 N. F. (2d) 725 (N. Y. 1941).

114. See pp. $387-90$ supra.

115. 252 App. Div. S42, 300 N. Y. Supp. 601 (1st Dep't 1937).

116. The case, however, had a peculiar sequence. Because if the rlaintiff's iailure to apply for a deficiency judgment under Section 1003-a the procects of the furcelesure sale were later held a complete satisfaction of the murtgage doht and a linuidatinn ly operation of law of the separate money judgment he had previrusly witainerl. Ruselizsh v. Rosenblum, 260 App. Div. 206. 20 X. Y. S. (2d) i25 (1st Derit 144i1), aff d, 234 N. Y. 745,31 N. E. (2d) 509 (1940). 
deficiency judgment. The lower courts were in hopeless conflict ${ }^{117}$ but a prompt amendment to Section 1083-a disposed of the question by providing that the proceeds of a foreclosure receivership or assignment of rents go to the mortgagee, to the extent of the deficit resulting from the foreclosure sale, regardless of a deficiency judgment. ${ }^{118}$

Where a part of the mortgaged premises was taken in condemnation prior to foreclosure, the Court of Appeals has held that the mortgagee may satisfy his lien from the award without applying for a deficiency judgment under Section 1083-a. ${ }^{110}$ The court, however, did not answer a certified question then presented as to whether the presumption of payment, created by Section 1083-a, was limited to a foreclosing mortgagee seeking a personal deficiency judgment against an obligor. ${ }^{120}$ It is unsettled, therefore, whether this presumption bars the sale of securities delivered to the mortgagee as additional collateral. ${ }^{\mathbf{1 2 1}}$

117. Receiver's balance to mortgagee: Prudential Ins. Co. v. Adelphi Hall, Inc, 242 App. Div. 704, 272 N. Y. Supp. 917 (2d Dep't 1934); Metropolitan Life Ins. Co. v. Rosenfield, 153 Misc. 218, 274 N. Y. Supp. 531 (Sup. Ct. 1934). Contra: Bowery Sav. Bank v. Letienne, N. Y. L. J., May 3, 1934, p. 2142, col. 4 (Sup. Ct.); Bowery Sav. Bank v. Tenart Realty Co., N. Y. L. J., June 12, 1934, p. 2856, col. 4 (Sup. Ct.). Many additional cases pro and con appear in the New York Law Journal during 1934. Despite failure to recover a deficiency judgment, proceeds of fire insurance policies were awarded to the mortgagee [Petroff v. First Nat. Bank, 258 App. Div. 1007, 16 N. Y. S. (2d) 771 (3d Dep't 1940)] as well as refunds of taxes paid by mortgagee or receiver [Greel1wich Sav. Bank v. Paramount Holding Co., N. Y. L. J., Aug. 20, 1937, p. 445, col. 2 (Sup. Ct.) ; Irving Sav. Bank v. 128 East 60 St. Co., N. Y. L. J., June 2, 1938, p. 2660, col. 6 (Stup. Ct.) ; Bowery Sav. Bank v. Burchill Realty Co., N. Y. L. J., Oct. 11, 1938, p. 1075 , col. 3 (Sup. Ct.)].

118. N. Y. Laws 1934, c. 562. But see People v. Sexton, N. X. L. J., Jan. 25, 1941. p. 396 , col. 5 (Sup. $\mathrm{Ct}_{\text {.) }}$ (refund to owner where mortgagee paid taxes with funds as:signed by owner); People ex rel: 342 East 57th St. Co. v. Miller, 262 App. Div, 132, 28 N. Y. S. (2d) 258 (1st Dep't 1941) ; People ex rel. N. Y. Title \& Mitge. Co. v. Miller, 262 App. Div. 175, 28 N. Y. S. (2d) 430 (1st Dep't 1941) (tax reftunds). Before these cases the refund was occasionally given to the owner, as the "taxpayer," despite his assignment of the rents to the mortgagee. People v. Sexton, N. Y. L. J., Jan. 25, 1941, p. 396, col. 5 (Sup. Ct.).

119. Matter of City of New York, 273 N. Y. 62, 6 N. E. (2d) 98 (1937) ; Id. (Houghiton Ave.), 266 N. Y. 26, 193 N. E. 539 (1934) ; 1d. (Neptune Ave.), 271 N. Y. 331, 3 N. E. (2d) 445 (1936).

120. The Cyllene Co. v. Eisen, 272 N. Y. 526, 4 N. E. (2d) 431 (1936).

121. The Appeliate Division, Second Department, has permitted two mortgagees to resort to such security without application for a deficiency judgment. Westerbekc $v$. Bank of Huntington \& Trust Co., 248 App. Div. 632, 287 N. Y. Supp. 228 (21 Dep't 1936), aff'd, 272 N. Y. 593,4 N. E. (2d) 819 (1936). Accord, Amazon v. East N. Y. Sav. Bank, 168 Misc. 738, 3 N. Y. S. (2d) 141 (Sup. Ct. 1938), aff'd, 256 App. Div. 1072, 11 N. Y. S. (2d) 567 (2d Dep't 1939) (cash security) ; Pink v. S. M. H. Co, N. Y. L. J., May 3, 1937, p. 2217, col. 1 (Sup. Ct.) (collateral mortgage) ; cf. Lenucr v. Corso, 162 Misc. 500, 295 N. Y. Supp. 827 (Cty. Ct. 1937), aff'd, 258 App. Div. 839, 15 N.Y.S. (2d) 668 (3d Dep’t 1939) ; Blust v. Yonkers Nat. Bank, 260 App. Div. 947, 23 N. Y. S. (2d) 512 (2d Dep't 1940). But it has forbidden another mortgagee. Matter 
It is clear, however, that the presumption of payment applies generally to collateral bonds made payable to the mortgagee and given by third persons as further collateral. Civil Practice Act Section 1083-b permits offset of the value of the property in an action on a mortgage debt "which originated simultaneously with such mortgage and which is secured solely by such mortgage" in favor of any person "directly or indirectly or contingently liable therefor." "Secured solely by such mortgage" literally refers to the mortgage bond and excludes an additional collateral bond. But in Klinke a'. Sammels ${ }^{122}$ the Court of Appeals determined that "whatever inaccuracies in language there may be," the phrase "directly or indirectly or contingently liable therefor" indicated a legislative intent to apply the statute to a collateral bond. The collateral bond involved was delivered simultaneously with the bond and mortgage and for a sum equal to the mortgage debt. In a later case, City Bank Farmers Trust Company a'. Ardlca Incorporation, ${ }^{123}$ the collateral bond was delivered six years after the execution of the bond and mortgage and for only part of the mortgage debt. This bond was neither "secured solely" nor had it "originated simultaneously" with the bond and mortgage and, thus again. would have been excluded by a literal construction of the statute. By reading together Section 1083-b and companion moratorium statutes, the court found a general legislative intent to include this bond, and repudiated the literal meaning of the quoted parts of the statute it was construing. In City Bank Farmers Trust Company v. MICConnell, ${ }^{124}$ however, a collateral bond for part of the debt was delivered to a mortgagee in circumstances generally similar to the Ardlea case, with the distinction that the bond was delivered after the effective date of the moratorium statutes and included a waiver thereof. Without opinion the bond was held enforceable. ${ }^{105}$ It is noteworthy that the emergency statutes forbidding actions for principal during the emergency expressly forbid a waiver as against public policy, ${ }^{120}$ while no such provision appears in the statutes limiting money judgments. Yet in the Ardlea case the court found it unnecessary to confine

of Williams, 258 App. Div. 592, 17 N. Y. S. (2d) 335 (2d Dep't 1940) (assignment of legacy), (1940) 53 Harv. L. Rev. 1400; Lang v. N. Y. Joint Land Bank, 155 Mise. 779, 280 N. Y. Supp. 766 (Sup. Ct. 1935) (collateral chattel mortgage); Fay v. Rubenstein, N. Y. L. J., Mar. 27, 1934, p. 1467, col. 4 (Sup. Ct.) (collateral mortgage); Hedero Realty Co. v. Title Guar. \& Trust Co., 175 Misc. 1082 (Sup. Ct. 1941 ).

122. 264 N. Y. 144,190 N. E. 324 (1934).

123. 267 N. Y. 224,196 N. E. 34 (1935).

124. 284 N. Y. 686,30 N. E. (2d) 725 (1940).

125. An affirmance without opinion is unsatisfactory as a basis for conelusions. While affirming the result it does not necessarily endorse the reasoning of the lower court. Palmer v. Travis, 223 N. Y. 150, 119 N. E. 437 (1918); Marcus, Afirmance W'ihomt Opinion (1937) 6 FordHaM L. Rev. 212.

126. N. Y. C. P. A. \$1077-d. 
itself to the particular section of the emergency laws in issue and deduced a legislative intent from the entire statutory scheme.

There seems to be no reason for distinguishing between the right to enforce a collateral bond and the right to sell stocks and bonds given for the same purpose. Both are generally delivered when the obligor is in extremis. The only conclusion to be drawn is that problems of construction have not been entirely solved.

Validity. During the early thirties the various states enacted every form of emergency mortgage statute - laws delaying proceedings for foreclosure or extending periods of redemption; abolishing or reducing deficiency judgments by fixing minimum prices for sale or allowing fair and reasonable value as a credit irrespective of the amount realized; and refusing confirmation of sales, or confirming only on condition that fair credit be given on the debt. In general, emergency statutes are upheld if they are designed merely to postpone the ultimate remedy of the mortgagee, and provide the mortgagee with reasonable payments or other safeguards during the interim. ${ }^{127}$ In 1934 the Supreme Court of the United States in the Blaisdell case ${ }^{128}$ upheld a Minnesota emergency statute empowering the courts to extend temporarily the period of redemption, upon the owner's application, provided a reasonable share of the income or rents were applied in the interim toward interest, carrying charges, or the principal of the indebtedness as ordered by the court. Protection against waste was accorded the mortgagee. The right to apply for a deficiency judgment was deferred until the expiration of the extencled redemption period. The Court deemed the statute a reasonable modification of the mortgagee's remedy without serious impairment of his substantive right on the ground that neither the debt, purchaser's title, nor right to a deficiency judgment was affected and that mercly a reasonable extension of time was given. The emergency, according to the Court, justified temporary exercise of powers normally quiescent. Comparison was drawn to the power to give temporary relief from physical disaster and reliance was placed on the emergency rent cases. ${ }^{120}$

127. Beaver Cty. Bldg. \& Loan Ass'n v. Winowich, 323 Pa. St. 483, 486-88, 515, 187 Atl. 481, 482-83, 921 (1936), 3 U. P1TT. L. Rev. 54; Bunn, Impairment of Coniracts: Mortgage and Insurance Moratoria (1933) 1 U. of Crr. L. Rev. 249, 250; (1933) 47 HARv. L. Rev. 299, 301; and, generally, see Feller, Moratory Legislation: a Compara* tive Study (1933) 46 HARv. L. Rev. 1061, 1069.

128. Home Bldg. \& Loan Ass'n v. Blaisdell, 290 U. S. 398, 88 A. L. R. 1481, 1519 (1934).

129. Edgar A. Levy Leasing Co. v. Siegel, 258 U. S. 242 (1922) (and cases therc cited). These uphold statutes designed to cope with an acute housing shortage after the last war by permitting tenants to hold over after expiration of their leases on payment of a reasonable rental. 
But the decision, five to four, expressly depended an the safeguards included in the statute. ${ }^{130}$

Civil Practice Act 1083-a and other comprarable statutes do not pustpone foreclosure; they qualify and limit deficiency judgments. Tw sustain their validity two methods of appruach are pussible: (1) attempted reconciliation with the contracts clause of the Federal cinstitution, or (2) circumvention of constitutional questions on the ground that the statutes merely codify inherent powers of chancery. The New York courts are logically committed to the first because in the Dunkley case ${ }^{131}$ Kent had held equity unable to render a deficiency judgment. It follows that deficiency judgments are creatures of statute and the immediate question is whether a right so created is subject to retroactive modification or recall. This approach, however, runs prumptly into Bronson o. Kinzie ${ }^{132}$ and other decisions of the Supreme Court of the United States invalidating, under the contracts clause, statutes comparable to Section 1083-a. ${ }^{153}$ The specific statutes held void sought to limit deficiency judgments by forbidding sales for less than a prescribed fraction of the appraised value. The Bronson case recognized that a "remedy" may be made less convenient or mure tardy or difficult without impairment of the "obligation" within the cuntracts clause, ${ }^{124}$ but flatly held that a statute overstepped the bounds if it substituted appraised value for sale price as the basis of deficiency judgments.

The first New York cases testing the validity of the current murtgage moratorium laws involved the statutes staying actions for principal. ${ }^{153}$ These were readily upheld, on grounds similar to those in the Blaislell case, as a reasonable exercise of police power during a declared emergency. ${ }^{136}$ In its first test case, Klinke 2 . Samuels, ${ }^{137}$ the Court of Appeals

130. The limits of the doctrine became apparent in Worthen ( 0.1 . Kavanaugh, $2 / 5$ U. S. 56 (1935) (unanimously holding statute invalid which estended actionable defaut from 65 days to $2 \% / 2$ years, reduced penalty interest from $20{ }^{\circ} ;$ to $3{ }^{\prime}$ c, anl deprivid nurtgagee of possession during redemption period extended to $f$ years $)$.

131. Dunkley v. Van Buren, 3 Johns. Ch. 330 ( $\mathrm{X}$. Y. 181N).

132. 1 How. 311 (U. S. 1S43).

133. MicCracken v. Hayward, 2 How 601 (U. S. 1S4t); Gantly's Lesce v. Fuing, 3 How. 707 (U. S. 1845). The statutes involved in the Rromsem case and these cases vecto not labeled emergency statutes.

134. Sturges v. Crowinshield, \& What. 123. 20u (U. S. 1811); Kichmond Mtge. \& Loan Co. v. Wachovia Bank \& Trust Co., 300 C. S. 124, 128, 168 A. L. R. \&\$4, w11 (1937).

135. MicCarty v. Prudence-Bonds Co., 149 Mise. 13. 266 X. I. Suyp. 6zy (Sup. Ct. 1933) ; Sherwin v. Jonas, 149 Mlisc. 481, 267 X. Y. Supp. 754 (City Ct. 1933), reid as other grousts, 150 MIisc. 343, 269 N. Y. Supp. 121 (Sup. Ct. 1934); Loporto v. Druic, Co., 268 N. Y. 699,198 N. E. 565 (1935) : 269 N. Y. 1677,200 X. F. 54, afpeal dismissid, 299 U. S. 617 (1936).

136. Reliance was placed on the emergency rent cases, the brevity of the cmergensy period, and the requirement that interest and taxes be paid during the muraturium.

137. 264 N. Y. 144,190 N. E. 324 (1934). 
considered the validity of Civil Practice Act Section 1083-a, not a postponement statute but one modifying mortgagees' stubstantive riglits to deficiency judgments. With no discussion other than a recital of emergency conditions, the court concluded that "such legislation, reasonably seeking only temporary relief, is not unconstitutional." A few months later in the Guttag $^{138}$ case, the court referred to the statutory basis of deficiency judgments and remarked that it had used the language quoted "perhaps unnecessarily". It ruled, however, that the issue before it involved merely the construction, not the validity, of Section 1083-a. Stubsequently in Honeyman $v$. Hanan ${ }^{130}$ the court upheld the statute, but perhaps unnecessarily. There a mortgagee brought an action at law for the deficit after foreclosure. In the foreclosure action an application for a deficiency judgment had been denied and the mortgagee discontinued against the obligor in order to bring the law action. The Court of Appeals held the complaint legally insufficient. On appeal the Supreme Court of the United States remanded for specification of the precise constitutional question raised. ${ }^{140}$ The Court of Appeals then framed a narrow question, i.e., whether legislation is valid which requires deter. mination of deficiency judgments in foreclosure actions. ${ }^{141}$ And appeal on this point was dismissed on grounds of a lack of a federal question in the mere procedure of state courts. ${ }^{142}$ In Honeyman $v$. Clarkc, ${ }^{143}$ the Court of Appeals again affirmed the validity of Section 1083-a on the basis of its earlier decisions.

Outside New York, statutes comparable to Sections 1083-a have gencrally been invalidated by state courts. In Beaver County Building o Loan Association v. Winowich, ${ }^{144}$ a well articulated Pennsylvania decision, three reasons for the invalidity of this type of statute were advanced. The argument based on the brevity of the emergency period was dismissed on the ground that, regardless of the duration of the legislation, the mortgagee's loss was permanent. It was also observed that change from an obligation for cash to an obligation for some cash plus "fair value" of the property as determined in the absence of sales gave the mortgagee no assurance that he could ever realize that value. The

138. N. Y. Life Ins. Co. v. H. \& J. Guttag Co., 265 N. Y. 292,192 N. E. 481 (1934).

139. 271 N. Y. 564,3 N. E. (2d) 186 (1936).

140. 300 U. S. 14 (1937).

141. 275 N. Y. 382,9 N. E. (2d) 970 (1937).

142. 302 U. S. 375 (1937) ; cf. Lapp v. Belvedere, 116 N. J. L. 563, 184 Atl. 837, 115 A. L. R. 429,435 (1936) (statute valid requiring joinder of obligor in forcclosure as condition precedent to subsequent action for deficit).

143. 278 N. Y. 467,17 N. E. (2d) 131 (1938), aff'd sub nom. Honeyman v. Jacolss, 306 U. S. 539 (1939).

144. 323 Pa. St. 483, 515, 187 Att. 481, 921 (1936) (collecting cases in accord), (1930) 3 U. of Pitr. L. Rev. 54 ; see cases cited in Note (1938) 115 A. L. R. 435, 436. 
realism of this approach becomes apparent where the income is insufficient and the mortgagee must "feed" the property for part or all taxes and carrying charges until the hypothetical "fair value" of the experts can be obtained, if ever. Finally, the court noted that a sale to an uutsider at foreclosure for less than the "fair value" gives the mortgagee nuthing in return for the enforced credit. The reasoning of this cuurt appears conclusive against validity if deficiency judgments are based upon statute.

In Honeyman v. Jacobs, ${ }^{145}$ the United States Supreme Court cunsidered for the first time in justiciable form the constitutionality of Section 1083-a and held it valid. The shadow of Bronson a. Kintic was avoided by the chancery approach. The Court cited the Blaisdcl! case, which is readily distinguishable, as well as the Irachoria case, which sustained a North Carolina statute, retrospective in application but limited in scope. ${ }^{140}$ The temper of the Court in the IFachozit case was indicated by its observation that the mortgage loan transaction cuntemplated such credit for the value of the property as would make the mortgagee whole, not enriched. This idea was repeated in Honteymas v. Jacobs, where the Court was impressed by the fact that the mortgayie had acquired property appraised at $\$ 25,000$ through a murtgage loan of $\$ 15,000$. The record did not, however, require consideration of the effect of acquisition of the property by a third person at the foreclosure sale for less than "fair value". The Court stated:

"Section 1083-a in substance assured to the cuurt the exurcise of its appropriate equitable powers. By the normal exercise of these powers, a court of equity in a foreclosure suit would have full authority to fix the terms and time of the foreclosure sale and to refuse to confirm sales upon equitable grounds where they were found to be unfair or the price bid was inadequate. . . . In this control over the foreclosure sale under its decree, the court could consider and determine the value of the property sold to the mortgagee and what the mortgagee would thus realize upon the mortgage debt if the sale were confirmed." $14 \pi$

145. 306 U. S. 539 (1939), 52 HARv. L. Rev. 1317; (193") 39 CHLo L. Rew. 1327.

146. Richmond Mitge. \& Loan Corp. v. Wachuvia I ank \& Trut Co., 3Uy U. S. 124,

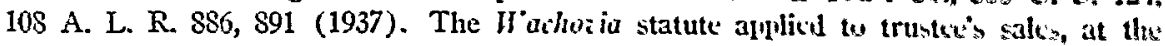
instance of the mortgagees, where title was acquired ly murtgagets fur less than this: debt, and provided that in a subsequent action for the residue the whligor coull offest the value of the property. This statute did not cover sales the third jursoms and therily avoided one of the objections pointed out in the IFinwaich ease. Fipually ingurtant, it left untouched another complete remedy of the murtgagee-the urdinary juticial saland thereby avoided complete impairment of remedy as in Eromson a. Kinsic. Its 24ras=tical effect, however, was a brake on deficiency judgments bicause deficienty julgments through judicial sales were already under equitable cuntrul in Nirth Carulins. See (1939) 52 Harv. L. Rev. 1367.

147. 306 U. S. 539,543 (1939). 
The language of the Court indicates a sanction of equitable control over deficiency judgments through control over the sale, at least where the mortgagee himself purchases, regardless of emergency conditions. 'This implication, however, was rejected by the New York Court of Appeals.

New York's restriction of its emergency mortgage laws to mortgages made before July 1, 1932, prevented control under Section 1083-a of deficiency judgments on subsequently executed mortgages. ${ }^{148}$ Upon recommendation of a legislative commission which relied on the Wachoviat case, the provisions of Section 1083-a were made part of the permanent law. In National City Bank v. Gelfert, ${ }^{1+0}$ however, the Coturt of Appeals, following Bronson v. Kinzie, held the new statute invalid insofar as it applied to preexisting mortgages, i.e., mortgages made between $\mathrm{Jt1ly} 1$, 1932, and April 7, 1938. The court stressed the fact that the stattute enacted a permanent and not an emergency change in remedy. Conceding normal state control over remedies in which a litigant has no vested interest, the court decided, nevertheless, that the statute had withdrawn all effective remedies. The two other available remedies - action on the bond and action for the deficit after foreclosure - were regarded as inadequate. An action for the deficit was deemed unduly hampered by the consolidation statutes and an action on the bond, in lieu of foreclosure, was held unsatisfactory because any judgment recovered could not be used to levy on the debtor's equity of redemption. ${ }^{150}$ In contrast to the emphasis of the Court of Appeals it is noteworthy that limitations upon the practical efficiency of alternative remedies received slight consideration in the Wachovia case.

The mortgagee in the Gelfert case had purchased at the foreclosure sale but the court's attitude was conditioned by the opportunity of thirdparty purchasers to bid at the sale. It remarked that the new statute compelled the mortgagee to bid a sum equal to:

"the market value as that value may thereafter be determined by the court or must go without any satisfaction of so much of the debt as equals the difference between the value as so determined and a lower price paid on a sale to a third party." 101

The court concluded that this factor left "no room for the play of any equitable consideration" and characterized as utterly capricious efforts

148. N. Y. Trust Co. v. Gude, 246 App. Div. 784, 284 N. Y. Supp. 233 (2d Dep't 1935); Decker v. Dutcher, 247 App. Div. 689, 289 N. Y. Supp. 553 (3d Dep't 1936); Chase v. Harvey, 253 App. Div. 15, 1 N. Y. S. (2d) 541 (3d Dep't 1937).

149. 284 N. Y. 13,29, N. E. (2d) 449,130 A. L. R. 1472,1482 (1940), revid, 313 U. S. 221 (1941).

150. N. Y. C. P. A. $\$ \S 710,711$; Tice v. Annin, 2 Johns. Ch. 125 (N. Y. 1816). The purpose is apparently to prevent foreclosure by means of attachment. 2 PivGR, MorTGAGES (1893) § 1561 .

'151. 284 N. Y. $13,21,29$ N. E. (2d) 449,453 (1940). 
of the lower courts to exert an independent equitable control aver deficiency judgments. ${ }^{152}$

The Gelfort case was reversed by the. Supreme Court ${ }^{1: 0}$ un the grouml that a mortgagee has no constitutional right to retain the strategic advantages of a forced sale and that a formula for fixing deficicncy judgments, restricting the mortgagee to payment in full, may be retriactively adopted. The Bronson and similar cases were by-passed as incapable of forcing "legislatures to be blind to the lessons which anther century had taught." Though adverting to equity's long efforts to fircvent judicial sales from becoming an instrument of ofpression, the Court premised its decision upon a legislative power. free of constitutional bars, to modernize the yardstick of value. The Jacobs case had merely indicated that Section 1083-a had codified a power inherent in equity. The Gelfert decision, however, expressly left open the yet uniktermined issue of the applicability of the new statute in cases where the premises are purchased by a third person. It would be extraordinary if this question were not soon presented, with an accompanying arsument on behalf of a mortgagee that the proceeds of a foreclosure sale can not be forced upon a creditor by retroactive fiat as full payment of the mortgage debt.

Inherent in this question is the entire basis of deficiency julgment and the technique and scope of equitable control. Although the Court of Appeals has repeatedly spoken of deficiency judgments as creatures of statute, it had held in the Frank case, ${ }^{154}$ long before the emersency, that the right to a money judgment in foreclosure was not fully defined ly statute. The empowering statute under consideration contemplated the determination of a deficiency judgment on the basis of the price oltained at the foreclosure sale. But a junior mortgagee subsequent to initiation of a foreclosure action was precluded from realizing on a sale

152. 284 N. Y. 13, 18-20, 29 N. E. (2d) 449, $451-52$ (1040). The MIgrtlate Lin is ins, Second Department, had previously waged an unequal struggle with the cisurt wi Arrculin an effort to establish equitable control over deficiency judgments. Six MLunghan : May, 242 App. Div. 64, 273 N. Y. Supp. 475 (2d Depit 1934); Emigrant Inilutt. Sav. Bank v. Van Bokkelen, 269 N. Y. 110, 116, 199 N. E. 23,25 (1935) ; Gusrantce Title: Mtge. Co. v. Scheffres, 247 App. Div. 294, 205, 285 N. Y. Supp. 4tot, 465 (2d Ligit 1936), second appeal, 249 App. Div. 652, 292 N. Y. Supp. 941 (21 Depit 143w), rivi,

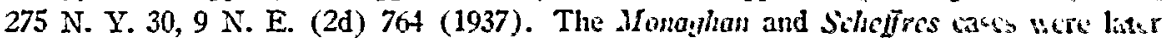
cited with approval in Honeyman v. Jacobs, 306 U. S. 539, 543 (1939), 52 H.25s. L. Ka. 1367.

153. 313 U. S. 221 (1941).

154. Frank v. Davis, 135 N. Y. 275,31 N. E. 1100,17 L. K. A. 36 (18i3). Aciourd, Sautter v. Frick, 229 App. Div. 345, 242 N. Y. Supp. 369 (th Dep't 19311, aff d, 256 N. Y. 535, 177 N. E. 129 (1931) ; Weisel v. Hagdalnl Kealty Co. 241 A1. Liv. 314, 271

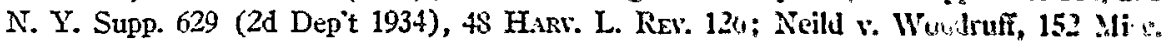

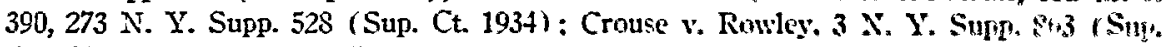

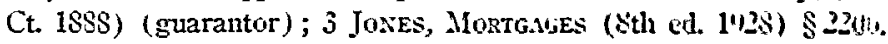


by a paramount foreclosure, and thus the deficiency uncler the junior mortgage could not be ascertained in the mode specified by stattute. Under these circumstances it was urged that the junior mortgagee could proceed no further in equity but must begin anew at law. Repudiating this argument, the Court of Appeals found no reason for limiting chancery's jurisdiction in foreclosures and ruled that equity could make a complete determination for the purpose of awarding a deficiency judgment.

Furthermore, the generally accepted belief that deficiency judgments are beyond the scope of equitable jurisdiction was seriously challenged after an exhaustive survey by Botts, J., in Young v. Vail. ${ }^{155}$ The American decisions were traced directly to the Dunkley case but the Dunklcy case was impeached on the ground that the English atuthorities relicul upon were irrelevant. The old English mortgagee, vested with legal title after default, went into chancery to stave off equitable interference with his right of ejectment. His purpose was to cut off the equity of redemption and confirm his legal title. A judicial ascertainment of the amount of debt was necessary in order to fix the terms of redemption but the object of the suit was to fix rights in rem, not to collect a debt. With this accomplished, complete relief was afforded. No money judgment was sought or given. Botts, J., concluded, therefore, that the authorities relied upon by Kent had no bearing because the precise question did not arise under the early English practice. Foreclosure by sale, on the other hand, generally presupposed title in the mortgagor, and involved neither "foreclosure" nor "equity of redemption" in the technical sense in which these terms were transplanted from England. It was, Botts, J., observed, a remedy for collection of a debt in which enforcement of a lien was only an incident. The opinion concluded by observing that in the Frank case the Dunkley doctrine was repudiated in the jurisdiction that gave it birth.

If equity jurisdiction over deficiency judgments be assumed, the technique of its exercise requires consideration. One suggestion, apparently never carried out, is based upon a supposed power in chancery courts to preclude mortgagees from biddling at foreclosure sales. ${ }^{150}$ The right to bid is now generally codified by statute ${ }^{157}$ and in New York foreclosure judgments provide that the plaintiff or any other party may bid "unless otherwise specially ordered by the court."168 This phrase "obvi-

155. 29 N. M. 324, 222 Pac. 912, 34 A. L. R. 980, 1015 (1924).

156. See Very v. Russell, 65 N. H. 646, 23 Atl. 522 (1874); Heighe v. Evans, 164 Mdd. 259, 269, 164 Atl. 671, 676 (1933); 3 Jones, Mortanges (7th ed. 1915) \$\$ 1614al, 1635,$1876 ; 2$ Wiltsie, Mortgage Foreciosures (5th ed. 1939) $\$ 675$.

157. Louisville Bank v. Radford, 295 U. S. 555, 580 (1935); 3 Jones, Mokrciatik:s (8th ed. 1928) §2101; 19 R. C. L. \$390, p. 577.

158. N. Y. Rules Civ. Pract. $\$ 259$; Brown v. Frost, 10 Paige 243,247 (N. Y. 1843); Mott v. Walkly, 3 Edw. Ch. 622 (N. Y. 1842). 
ously was intended to give the court power to revive the old rule if circumstances should prove that the mortgagee's right to bid was being abused." ${ }^{259}$ The suggestion is in terrorem. It disclualifies the logical bidder who can prevent the property from going for a sung, makes both parties helpless, and increases the amount of the deficiency judgment. ${ }^{100}$ Whatever is left, or ever existed, of the rule is centered about sales by a mortgagee under a power. or other circumstances in which he controls the conduct of the sale. ${ }^{161}$ It thus prevents a mortgagee from selling to himself. The dubious applicability of the principle to judicial sales is shown by the New York cases indicating that the purpose of its rule of court is "to avoid all question" 162 and "to avoid the effect of a supposed technical rule." ${ }^{163}$ It is a bit of English practice which does not obtain in this country ${ }^{104}$ and apparently nerer existed in New York. ${ }^{105}$ In England the rule applies to non-judicial sales ; ${ }^{160}$ its observance in judicial sales consists of routine applications fur leave, probably unnecessary, which are given as a matter of course. ${ }^{167}$ The rule cannot have been an important part of control by American equity courts uver deficiency judgments and any resurrected form would be clumsy:

Deficiency judgments have recently been subjected to contrul by means of the power to give or refuse confirmation of foreclosure sales. In Suring State Bank i'. Giese, ${ }^{168}$ a Wisconsin court made cunfirmation conditional upon allowance of credit for the fair value of the property,

159. Gilligan \& Stern, Protccting the Rights of Mort!nutors, X. Y. L. J., Aug. 29, 1933, p. 688, col. 1; Id., Aug. 30, 1933, p. 702, col. 1 ; see (1933) 47 H.Ms. L. ILw. $21 \%$, 305 , n. 48.

160. Twin-Lick Oil Co. v. Marbury, 91 U. S. 587, 590-91 (1875); Felton v. LeBretent, 92 Cal. 457, 466, 28 Pac. 490, 493 (1891); Chillicothe Paper Cu. v. Whoeler, 6S Ill. Alyj. 343,348 (1896).

161. Bergen v. Bennett, 1 Caines Cas, 1, 19 (N. Y. 1804); Roherts v. Flemming, 53 I11. 196 (1870); Felton v. LeBreton, 92 Cal. 457, tot, 28 Pac. 490,493 (1841); $d$. Bennett v. Austin, 81 N. Y. 309, 327 (1880).

162. Elliot v. Wood, 45 N. Y. 71, 79 (1871); if. Fulton v. Whitney, 6i X. Y. 548 , 557 (1876).

163. Conger v. Ring, 11 Barb. 356. 360 (N. Y. 1851); if. E.r farte Ashley, 3 Deac. \& C. $510,518-19$ (N. Y. 1833 ).

164. Pewabic Mining Co. v. Mason, 145 U. S. 349, 301-1.2 (1892); Mcilair v. Bitdle, 8 MIo. 257, 265 (1S43).

165. Thontas, Mortanges (3d ed. 1914) \$1044.

166. Ex partc Davis, 3 Deac \& C. 504 (N. Y. 1833); Gunn v. Juhnsun, to D. L. K. 656 (Alberta 1919) ; 2 Coote, Montgages (Sth ed. 1912) 935, 1075-70; see 25 Halsal nY Laws 316 (1913).

167. Ex parte Ashley, 3 Deac. \& C. 510. $518-19$ (N. Y. 1834) (usual practice thugh "not absolutely necessary"); Ex parti Pedder, 3 Deac \& C. (1.22 (N. I. 1834) (given sutne pro tunc).

168. 210 Wis. 489,246 N. W. 556,85 A. L. R. 1477, 14 저 (1933). Wisensin mos: applies the doctrine where the disparity between bid and value is "shoding." W'cimer v. Uthus, 217 Wis. $56,258 \mathrm{~N}$. W. 358 (1935). 
"a novel procedure for relieving mortgagors from deficiency judgments." 160 New Jersey inaugurated a similar practice. There, foreclosures were prosecuted in equity after which an action at law lay for the deficit. A statute was enacted permitting the obligor to defeat the law action to the extent of the value of the property. Though this statute was held invalid, ${ }^{170}$ the New Jersey equity courts carried out its purpose by refusing to confirm sales, or reserving the right to vacate them, unless the fair value of the property were allowed upon the mortgagee's claim. ${ }^{171}$ This method is not available in New York practice where confirmation is unnecessary ${ }^{172}$ and delivery of a referee's deed passes immediate title. ${ }^{173}$ It is makeshift in its interference with title for an ulterior purpose. The stabilizing effect of the rule against setting aside the sale for inadequacy of price alone is essential to attract bidders. And there is no reason for refusing confirmation except on grounds that would justify vacation of the sale. If equity has plenary jurisdiction in foreclostures, subterfuge may be avoided by a frank assumption of power to value the premises in measuring the claim in personam. But if the power be assumed, the problem of appraisal remains and cannot be solved by use of empty terms like "fair value" or "market value." The issue is essentially one of balancing equities, for which ample precedent exists. Objections based upon the possibility of capricious results are directed not against this doctrine alone but generally against discretionary power in courts of original jurisdiction, the abuse of which is presumably corrected by appellate tribunals.

\section{CONFLICT OF LAwS}

Our discussion of the mortgagee's rights in personam began with the common law. The rights and limitations which the consolidation statutes, the emergency statutes and the permanent deficiency judgment law super-

169. See (1933) 42 Y ALE L. J. 960, 961.

170. Vanderbilt v. Brunton Piano Co., 111 N. J. L. 596, 169 Atl. 177, 89 A. L. K. 1080 (1933).

171. Young v. Weber, 117 N. J. Eq. 242, 175 Atl. 273 (Ch. 1934); see Federal 'T'itle Mtge. Guar. Co. v. Lowenstein, 113 N. J. Eq. 200, 166 Atl. 538 (Ch. 1933); but d. Broadman v. Colonial Bldg. \& Loan Ass'n, 118 N. J. Eq. 275, 178 Atl. 775 (1935) (value no defense in law action except as fixed in foreclosure). The current trend in $\mathrm{Ncw}$ Jersey is to refuse confirmation for inadequacy of bid only as to necessitous mortgagors. And confirmation has been given on a bid for less than fair value where the discreprancy between bid and value is not "unconscionable." See Fidelity Union Trust Co. v. Ritz Holding Co., 126 N. J. Eq. 148, 8 A. (2d) 235 (1939), (1941) 89 U. of PA. L. Rev. 104.

172. See pp. 384-85 supra.

173. Tuthill v. Tracy, 31 N. Y. 157 (1865); Giles v. Comstock, 4 N. Y. 270 (1850); Farell v. Noel, 17 App. Div. 319, 322, 45 N. Y. Supp. 207, 209 (1st Dep't 1897). Be. tween sale and delivery of deed the purchaser has equitable title. Matter of Braico, 235 App. Div. 132, 256 N. Y. Supp. 483 (2d Dep't 1932), aff'd, 260 N. Y. 625, 184 N. L. 120 (1932); Williams v. N. Y. Zinc Co., 29 F. (2d) 167, 171 (C. C. A. 2d, 1928). 
imposed upon the common law gave rise, as we have sten, to certain important problems. Conflict of laws raises several additional prublems involving the requirement by the situs of leare to sue after forclusure, offset of value permitted by the situs, and discharge of the deht by the law of the situs.

Before the Emergency Mortgage Lazis. Generally, statutes designet to consolidate the mortgagee's remedies have been held by fureign cuurts to have no effect upon the transitory character of the mortgasee's cau=e of action for the debt or balance of the deht. ${ }^{174}$ Consequently, since Section 1078 has been held a local statute, limited to New Iurk fureclosure actions, leave to sue in New York for the residue of the delit after a foreign foreclosure is not required. ${ }^{175}$ In the alsence of pronif to the contrary, it is assumed that the foreclosure sale was reucular and brought the fair value of the land. ${ }^{170}$ If the obligur was nut servel. however, the foreign foreclosure merely has the effect of establishing the mortgagee's title to the mortgage and right to fureclose. Persunal liability is not adjudicated thereby, and in a subsequent action the ullisin or may set up any defense to liability including impropriety in the foreclosure sale. ${ }^{177}$

Likewise, Section 1078 has been deemed to relate solely to actirns in New York, and thus to have no effect outside the state. In Belmm 8 . Comen, ${ }^{178}$ a Connecticut court permitted recovery of a deficit remaining after a New York foreclosure without requiring special leave from the New York court. The court denied that the New York courts had any control over foreign actions on the theory that granting extraterritnrial effect to the New York consolidation statutes would lead tin alsurd results. ${ }^{179}$ For example, under the New York consolidation statutes an

174. See Note (1926) 42 A. L. R. 470,480 ot seq.: (1007) 30 H.nn. L. Rrs 324; 41 C. T. $\$ 646-b$, p. 656 . For a discussion of various comparable statutes, cre Nutes (1437) 108 A. L. R. 397, (1939) 121 A. L. R. 917, 926 at seq.: Camment 11937 , 25 Cvif. I. REv. 576.

175. N. Y. Life Ins. Co. v. Aithin, 125 N. Y. 660,26 N. E. 732 (1891); I7lurida Land

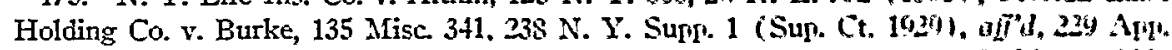
Div. 853, 243 N. Y. Supp. 799 (1st Dep't 1930): Mutual Life Ins. Co. v. Smith, 19 Ah?. N. C. 69 (N. Y. 1887) ; Cape Cod Sav. Bank v. Patton, N. Y. L. I.. AIr. 11, 1934, 1.

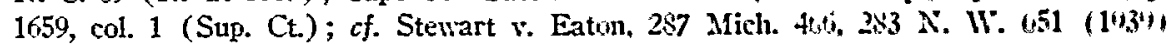
(comparable Michigan statute).

176. N. Y. Life Ins. Co. v. Aithin, 125 N. Y. $660,675,26$ N. E. 732, 736 (1891).

177. Natter of James, 146 N. Y. 78. 40 N. E. $\$ 76$ (1845); Stewart : Eatron, 207 Mich. 466,283 N. W. 651,120 A. L. R. 1354, 136 (1939) : ste Durant Y. Iliendremb, 97 N. Y. 132, 141-42 (1S84); Howard v. MeNaught, 9 Wash. 355,37 Pac. 455 (1894).

178. 48 Conn 338 (1S80).

179. For similar reasons California, which limits the right of a mortgagee to furcclosure and a judgment for the deficit, refused to apply its cunsulidation requiremsnts t." proceedings to enforce deficits after foreign foredusures. Lenver Sthelyards Lanl: v. 
action against a guarantor in Connecticut would be stayed by the pendency of a New York foreclosure; or a mortgagee bringing actions in New York and Connecticut on a mortgage covering property in both states would have to obtain leave of the New York court before he could enforce all his security. Moreover, though Connecticut practice allowed deficiency judgments based on appraised value of the property, the court in the Belmont case held evidence of market value incompetent on the ground that, under New York practice, the mortgagee received the proceeds of the foreclosure sale rather than the property itself. That is, market value was deemed immaterial by the court, which felt that, if it were considered, the obligor might be credited with more than the mortgagee's actual receipts. ${ }^{180}$ Again, in Williams \%. Follctt, ${ }^{181}$ a mortgagee who had foreclosed in New York after the death of the bondsman was permitted to file a claim in Colorado against the latter's estate without obtaining special leave, on the ground that the New York statute "applies only to actions against those who might, by virtue of the act, be made parties to the original foreclosure proceeding." 182 Neither case, however, can be criticized too severely, inasmuch as a New York court would probably, under the prevailing New York rule, have awarcled the mortgagee a judgment for the deficit shown by the sale, particularly if the obligor were unavailable for service in the New York foreclosure. ${ }^{183}$ Thus, it can be said that these decisions give the mortgagee no more than was contemplated by the New York law while refusing to take into account the accident of the defendant's whereabouts. ${ }^{184}$

Comparable consolidation statutes outside of New York have received various constructions. New Jersey, for one, limits the mortgatgee to foreclosure in the first instance. Within three months after foreclosure he is permitted, on filing a notice of pendency of action, to bring an action at law for the deficit; recovery of a money judgment reopens the foreclosure and permits redemption within the following six months. New Jersey, it must be noted, applies its own rule only to local mort-

Martin, 177 Cal. 223, 170 Pac. 428 (1918) ; Maryland Casualty Co. v. Nottingham, 18 Cal. App. (2d) 135, 63 P. (2d) 864 (1936).

180. Accord, Fidelity-Bankers Trust Co. v. Little, 178 S. C. 133, 181 S. E. 913 (1935) (Tenn. foreclosure) ; Howard v. McNaught, 9 Wash. 355, 37 Pac. 455 (1894) (Kan. foreclosure).

181. 17 Colo. 51, 28 Pac. 330 (1891). Cf. Lockwood v. Fawcett, 17 Hin 140 (N. Y. 1879), cited supra note 51.

182. 17 Colo. 51, 54, 28 Pac. 330, 331 (1891).

183. But see Morgan v. Sherwood, 53 Ill. 171 (1870), where after the foreclosure of a New York mortgage in which the mortgagor's representative was made a defendant the filing of a claim against the estate was permitted in Illinois. Apparently, the application of N. Y. C. P. A. § 1078 was not raised.

184. Compare Hutchinson v. Ward, 192 N. Y. $375,380,85$ N. E. 390,392 (1908); Felton v. West, 102 Cal. 266, 269, 36 Pac. 676, 677 (1894). 
gages. ${ }^{185}$ Yet foreign courts have consented to apply it to New Jersey mortgages except where both execution and place of payment were outside New Jersey. ${ }^{186}$ Thus, Pennsylvania has denied recovery on a New Jersey mortgage debt where foreclosure proceedings were not first instituted, ${ }^{187}$ and New York has indicated its concurrence. ${ }^{189}$ On the other hand, foreign courts have not construed the California rule limiting the mortgagee to a single action of foreclosure and deficiency judgment as prohibiting actions for the debt before ${ }^{159}$ or during ${ }^{139}$ California foreclosures or for a deficit thereafter. ${ }^{101}$ Such a construction has been justified as preventing evasion of personal liability. But if complete relief were available in the California foreclosure through jurisdiction in personam, there would be no excuse for entertaining another action on the bond elsewhere, thus permitting multifariousness and a recovery possibly in excess of that fixed by the policy of the situs.

In actions for the residue of the debt after New Jersey foreclosures, New York has ruled that the mortgagee's failure to file a lis pendens under the New Jersey statute does not affect the bond as a cummon law

185. Colton v. Salomon, 67 N. J. L. 73, 50 Atl. 588 (Sup. Ct. 1901). The statute is inapplicable where the mortgage secures a note rather than a bond. Asbury Parl: \& Ocean Grove Bank v. Giordano, 3 N. J. Misc. 555, 139 Atl. 202 (1925), aff'd, 103 X. J. L. 171, 134 Atl. 915 (1926).

186. Thompson v. Lakewood City Development Co., 105 Misc. 680, 174 X. Y. Sugp. 825 (Sup. Ct. 1919), aff'd, 188 App. Div. 996, 177 N. Y. Supp. 926 (21 Dep't 1919); Hall v. Hoff, 295 Pa. St. 276, 145 Atl. 301 (1929); see Van Hurn v. MlcInnes Erich Mifg. Co., 5 Penn. Dist. Ry. 701 (1896). But delivery of a New Jersey mortgage and submission to New Jersey jurisdiction in foreclosure has been held to make New Jercey law control. McGough v. Derby, 254 App. Div. 708, 3 N. Y. S. (2d) 753 (2d Dep't 1938) ; see Bronson v. Kinzie, 1 How. 311,315 (N. Y. 1843); Harris v. Metrugulitan Cas. Co., 156 Misc. 692, 693, 282 N. Y. Supp. 449,450 ( Mun. Ct. 1935), (193b) 36 Cut. L. REv. 487.

187. Newman v. Brigantine Beach R. R., $15 \mathrm{~Pa}$. Cu. Ct. (125 (1894); sce Sea Grure Bldg. \& Loan Ass'n v. Stockton, 148 Pa. St. 146. 148-52, 23 Atl. 1063, 1064-65 (1892).

188. Hutchinson v. Ward, 192 N. Y. 375, 379-80. 85 N. E. 390, 391 (1008); Stum, i v. Hallahan, 101 App. Div. 383, 386, 91 N. Y. Supp. 1062, 1063 (1st Dep't 1005), aff'd, 185 N. Y. 550, 77 N. E. 1196 (1906); Robinson Y. Stratman, 141 Mise. 393,252 X. Y. Supp. 557 (Sup. Ct. 1931) (Fla. statute).

189. Maxwell v. Ricks, 294 Fed. 255 (C. C. A. 9th, 1923); Mantle v. Dabney, 47 Wash. 394, 92 Pac. 134 (1907).

190. Dolbear v. Foreign Mines Devel. Co., 196 Fed. (jt6 (C. C. A. 9th, 1912).

191. Commercial Nat. Bank v. Catron, 50 F. (2d) 1023 (C. C. A. 10th, 1931); Mackintosh v. Gibbs, 79 N. J. L. 40, 74 Atl. 708 (Sup. Ct. 1909), aff'd, 81 X. J. L. 577, 80 Atl. 554 (1911). Contra: Lindsay v. Collings, 182 S. W. 870 (Tex. Civ. Arp. 1916) (though no personal jurisdiction in California foreclosure). A Muntana statute, similar to that of California, is given no extraterritorial effect. MeGirl v. Brewer, 132 Ore, 422, 285 Pac. 208 (1930) ; Fischer v. Jackson, 239 Ill. App. 322 (1925). California lass liniited its statute to local foreclosures. Felton v. West, 102 Cal. 266, 36 Pae. 676 (1894); Denver Stockyards Bank v. Martin, 177 Cal. 223, 170 Pac. 423 (1918); Maryland Cas. Co. v. Nottingham, is Cal. App. (2d) 135, 63 P. (2d) Set (1036); MeGute v. Romml, 148 Cal. 539, 83 Pac. 1000 (1906); see First Trust Fank v. Meredith, 5 Cal. (2.1) 214 (1936). 
obligation, though, clearly, refusal to penalize such an omission defeats the New Jersey policy of warning purchasers that the mortgaged premises are subject to redemption. ${ }^{192}$ It must be noted, however, that statutes of this type, which do not purport to discharge the debt, ${ }^{103}$ should be distinguished from other statutes providing that foreclosure exhatusts the mortgagee's remedies, ${ }^{194}$ or that the mortgagee's failure to stue for the deficit within the statutory period results in a lapse of his cause of action. ${ }^{195}$ Statutes of the latter type are generally followed.

Under the Emergency Mortgage Lawe. In actions brought in New York for a debt or residue of a debt after a foreign foreclosture it has been held that a mortgagor could not offset value under Section 1083-b. New York holds that its emergency mortgage statutes apply only to actions based upon local mortgages. ${ }^{106}$ Since only local mortgages may be foreclosed in New York and since Section 1083-b has been grouped among the statutes regulating mortgage foreclosures, the legislature has been regarded as thereby intending to restrict the right of offset to New York mortgagors. ${ }^{197}$ Such a construction has also been based tupon the belief that the legislature determined an emergency to exist solely within New York, ${ }^{108}$ although it seems more likely that the legislature gave no more thought to possible conflict of laws questions than the gentlemen who prepare law digests without making separate provision for this subject. It is noteworthy that in the cases involving this

192. Hackensack Trust Co. v. Voigt, 75 F. (2d) 270 (C. C. A. 2d, 1935) (and cascs there cited) ; Smith v. Mangin, 161 Misc. 288, 292 N. Y. Supp. 265 (Mun. Ct. 1936); (1907) 20 HARv. L. REv. 326. The failure to file a notice of pendency of action is justified by these cases on the ground that New Jersey construes this as a requirement for local actions. Bankers Fed. Sav. \& Loan Ass'n v. Burlingham, N. Y. L. J., Oct. 16, 1939 , p. 1142, col. 4 (Sup. Ct.), indicates that a lis pendens is now a prerequisite to atl action for the residue anywhere.

193. See Weed v. Caulkins, 24 Hun 582, 585 (N. Y. 1881).

194. Cape Cod Sav. Bank v. Patton, N. Y. L. J., Apr. 11, 1939, p. 1659, col. 1 (Sup), $\mathrm{Ct}$.) (mortgagee failed to show effect of Massachusetts non-judicial foreclosure on right to deficiency); Gates v. Tebbetts, 100 Mo. App. 590, 75 S. W. 169 (1903); Battle v. Battjes, 274 Mich. 267, 264 N. W. 367 (1936); cf. Denistoun v. Payne, 7 La. All. 333 (1852).

195. McGough v. Derby, 254 App. Div. 708, 3 N. Y. S. (2d) 753 (2d Dep't 1938); Wollen v. David, Inc., 247 App. Div. 113, 286 N. Y. Supp. 289) (1st Dep't 1936), aff'l, 272 N. Y. 626,5 N. E. (2d) 364 (1936).

196. Sce, generally, Bailey \& Rice, The Extratcrritorial Effect of the New York Mortgage Moratorium (1935) 20 CoRN. L. Q. 315 ; (1940) 40 CoL. L. REv. 867.

197. Provident Sav. Bank \& Trust Co. v. Steinmetz, 270 N. Y. 129, 200 N. E. 669 (1936) ; Integrity Trust Co. v. Posch, 13 N. Y. S. (2d) 973 (City Ct. 1939); Kecler v. Templeton, 164 Misc. 113, 298 N. Y. Supp. 193 (Sup. Ct. 1937) ; sec cases citcd infra note 199; (1940) 40 CoL. L. Rev. 867, 869; , but cf. Fromm v. Glueck, 161 Misc. 502, 293 N. Y. Supp. 530 (Sup. Ct. 1937) (set-off governed by forum).

198. Franklin Soc. v. Weseman, 162 Misc. 109, 293 N. Y. Supp. 909 (Mun. Ct. 1937), ibid, 170 Misc. 1000, 10 N. Y. S. (2d) 247 (Mun. Ct. 1937); General Bond is Mtge. Co. v. Yaffe, N. Y. L. J., Nov. 9, 1935, p. 1772, col. 6 (Sup. Ct.); Bailey \& Rice, loc. cit. supra note 196. 
issue either no provision had been made at the situs for offset or statutes giving such a right had been held invalid. ${ }^{193}$ But cascs are heginning to arise in New York in which extra-state mortgage statutes are being pleaded. New York has already given effect to a foreign discharge and there are indications that it will enforce an offset validly created by the law of the situs. ${ }^{200}$

Professor Lorenzen has pointed out that moratory legislation can lie effective only if, under a doctrine of reciprocity, a moratorium at the situs is recognized wherever the litigation takes place. ${ }^{201}$ His suggistion is reinforced today by an increasing tendency to enact purmantnt murtgage legislation designed to prevent a mortgagee's recovery, in rem and in personam, in excess of the debt. Unless regulations of the situs are enforced at the place of litigation - whether they involve offset of value in an action for the residue of the debt or limitations on the right tu sue - the state denying enforcement becomes a haven for litigation which is suppressed, at least in part, by the policy of the situs and invites a similar repudiation of its own policy. The few cases decided thus far indicate that New York, for one, will enforce an offset granted in another situs. But this is insufficient, even if followed elsewhere, $t$. effectuate the policy of the New York statutes. ${ }^{202}$ For if a New York foreclosure is obtained without personal jurisdiction, an actiun will lic in a foreign state for the difference between the amount of the obligation and the proceeds of the foreclosure sale, without adjustment for fair value. ${ }^{203}$ The only check on such an excessive recovery is the requirement of leave to sue imposed by Section 1078. If this statute is now disregarded as a local restriction on the "right to sue" or as an impotent effort to control foreign actions, as was held in Belmont $\boldsymbol{x}$. Comen, it is quite obvious that the policy of New York will be defeated.

199. See Hackensack Trust Co. v. Voigt, 75 F. (2d) 270 (C. C. A. 2.3, 1935); Ports v. Polachek, 150 Afisc. S91, 270 N. Y. Supp. S07 (AIun. Ct. 1934); Calvosa v. De Lusses, N. Y. L. J., June 6, 1935, p. 2927, col. 5 (Sup. Ct.); Bankers Loan Co. v. Whitcemi, N. Y. L. J., Miar. 9, 1938, p. 1166, col 3 (Sup. Ct).

200. Fidelity Union Trust Co. v. Silbert, N. Y. L. I. July 8, 1939, P. 59, col. 5 (Sul. Ct.), aff'd, 260 App. Div, 1002, 24 N. Y. S. (2d) 999 (1st Dep't 1'44): sce Fandscr Fed. Sav. \& Loan Ass'n v. Burlingham, N. Y. L. J., Oct. 16, 1939, 1. 1142, cul. 4 (Sug. Ct.); cf. Franklin Soc. v. Weseman, 170 Misc. $1000,10 \mathrm{Q2}, 10$ N. X.S. (2d) 247, $25 \mathrm{t}$ (Miun. Ct. 1939); Porte v. Polachek, 150 Misc 891, $894,270 \mathrm{~N}$. L. Surp. \$17, S111 (Mun. Ct. 1934).

201. MLoratory Legislation Relating to Bills and Notes and the Cenflict of Luics (1919) 28 YALE L. J. 324, 351.

202. In Bayside-Flushing Gardens, Inc v. Beuermann, 36 F. Supp. 705 (D. D. C. 1941), an action brought on a New York mortgage bond, defendint's answer sctting up an offset of value was stricken out. The decision that N. Y. C. P. A. $\$ 1033 \cdot b$ is "prescedural" overlooks the distinction between the use of this term in constitutional law atul conflict of laws. See Bailey \& Rice, supra note 196, at $31 \mathrm{k} \mathrm{ct}$ scy.

203. N. Y. C. P. A. $\$ 10 \& 3-b$, permitting offset of value in an action un the dibt, $j$ inapplicable to post-moratorium mortgages. 